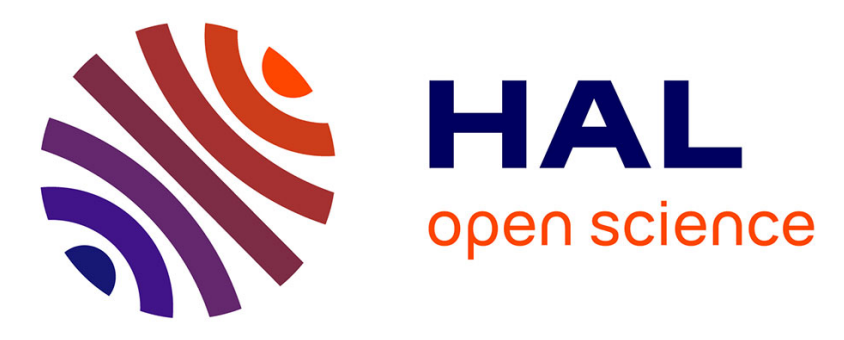

\title{
Cenomanian-Turonian organic sedimentation in North-West Africa: A comparison between the Tarfaya (Morocco) and Senegal Basins.
}

Pierre Nzoussi - Mbassani, N. Khamli, Jean-Robert Disnar, Fatima

Laggoun-Défarge, Mohammed Boussafir

\section{To cite this version:}

Pierre Nzoussi - Mbassani, N. Khamli, Jean-Robert Disnar, Fatima Laggoun-Défarge, Mohammed Boussafir. Cenomanian-Turonian organic sedimentation in North-West Africa: A comparison between the Tarfaya (Morocco) and Senegal Basins.. Sedimentary Geology, 2005, 177, pp.3-4, 271-295. 10.1016/j.sedgeo.2005.03.008 . hal-00023487

\section{HAL Id: hal-00023487 \\ https://hal-insu.archives-ouvertes.fr/hal-00023487}

Submitted on 23 May 2006

HAL is a multi-disciplinary open access archive for the deposit and dissemination of scientific research documents, whether they are published or not. The documents may come from teaching and research institutions in France or abroad, or from public or private research centers.
L'archive ouverte pluridisciplinaire HAL, est destinée au dépôt et à la diffusion de documents scientifiques de niveau recherche, publiés ou non, émanant des établissements d'enseignement et de recherche français ou étrangers, des laboratoires publics ou privés. 


\title{
Cenomanian-Turonian organic sedimentation in North-West Africa: A comparison between the Tarfaya (Morocco) and Senegal Basins
}

\author{
P. Nzoussi-Mbassania ${ }^{a}$, N. Khamli $\underline{b}$, J.R. Disnara $\stackrel{a}{ }$, F. Laggoun-Défarge ${ }^{a}$, and $M$. \\ Boussafir ${ }^{\mathrm{a}}$,
}

anstitut des Sciences de la Terre d'Orléans (ISTO), UMR 6113 CNRS-Université d'Orléans, Bâtiment de Géosciences, 45067 Orléans cedex 2, France ${ }^{b}$ Université de Tétouan, Faculté des Sciences, Département de Géologie, B.P. 2121, Maroc, France

\section{Abstract}

The Cenomanian-Turonian Oceanic Anoxic Event was recognised in North Western Africa in various depositional settings from abyssal areas to continental shelves. To derive information on environmental conditions in these different settings and define a depositional model, a petrographical and geochemical study of the organic matter was performed on sediments from the Tarfaya (Morocco) and Senegal Basins. The results obtained for these two locations were compared to those of previous studies, namely from DSDP wells.

Petrographic and geochemical data allow the differentiation of two main organofacies: a shallow depositional facies (continental shelf) is characterised by low total organic carbon (TOC) contents $(<4 \%)$. As attested by low hydrogen index $(\mathrm{HI})$ values (100 to $400 \mathrm{mg} \mathrm{HC} / \mathrm{g} \mathrm{TOC}$ ), the organic matter (OM) is moderately preserved. Petrographically, this facies is composed of mixed OM with high proportions of reworked vitrinite indicating detrital material influence. The depositional environment is typical of dysoxic conditions $(\mathrm{S} / \mathrm{C}<0.36)$ exposed to high mineral inputs and oxygenated water currents.

The second organofacies deposited in the deep marine environment (slope and abyssal) shows a high TOC content $(>7 \%)$. The predominance of fluorescing amorphous $\mathrm{OM}$ combined with high $\mathrm{HI}$ values suggests good preservation conditions. The S/C ratio (>0.36) and abundance of organic-sulphur compounds support this interpretation and indicate a development of anoxic conditions.

To explain the organic contrast between both environments a depositional model has been developed which is based on limited water exchange between both depositional settings. The main factor which has determined black shale sedimentation is the restricted water circulation related to the presence of isolated depositional environment during Atlantic Ocean opening. Compared to present upwelling zones, the palaeoproductivity in the studied area was relatively moderate during Cenomanian-Turonian and seems not to be the only determining factor of organic matter accumulation.

Keywords: Tarfaya Basin; Senegal Basin; Organic matter; Primary productivity; Euxinic 


\section{Introduction}

On the North African continental margin Cenomanian-Turonian (C-T) sediments have been recognised in present-day shelf and slope areas (Herbin et al., 1986, Leine, 1986, El Albani et al., 1999 and Kolonic et al., 2002). These formations have also been penetrated by several ODP and DSDP wells $(138,367,368$ Sites) and petroleum exploration boreholes (CM7, CM10) in offshore Senegal. C-T sediments also occur at outcrops along the Moroccan Atlantic coast (Herbin et al., 1986) and in Bahloul Formation in Tunisia (El Albani et al., 1999). Since the introduction of the concept of Oceanic Anoxic Events (OAE) by Schlanger and Jenkyns (1976), aiming to explain the organic richness of these units, there are still active controversies on the origin and the extension of this event. Many authors have discussed the main factors which are responsible for high OM contents usually found in these sedimentary formations (Lancelot, 1980, Waples, 1983, Busson and Cornée, 1996 and de Graciansky et al., 1984).

Euxinic conditions in a large part of the water column are presently considered one of the most susceptible mechanisms to explain black shale sedimentation in the North Atlantic area (Kuypers et al., 2002 and Lüning et al., 2003). This assumption is essentially supported by the presence of molecular biomarkers (isorenieretane) derived from photosynthetic green sulphur bacteria (chlorobiaceae) found both in the Tarfaya Basin (Kolonic et al., 2002) and the Senegal offshore (DSDP 367) (Sinninghé Damsté and Köster, 1998).

Based on recent work (Nzoussi-Mbassani et al., 2003) we assume that the supposed global anoxic conditions did not affect all depositional environments in the North Atlantic area and that organic matter sedimentation was also dependent on local paleogeographic and environmental factors. In addition, most of the work that has been done on C-T series lacked a comparison between shallow and deep environments that makes the establishment of a global depositional model for these formations difficult. The similarity of the geological evolution between the sedimentary Basins of Morocco and Senegal gives us the opportunity to compare the C-T sediments in these two areas, along the Western coast of the Atlantic Ocean.

The present study includes petrographic and geochemical analyses from both the Senegal platform and the Tarfaya Basin (Morocco) in order to compare sediment characteristics, and especially organic matter contents. These data are compared to other C-T occurrences in the study area to propose a depositional model for the North African margin area.

\section{Regional geological setting}

The geological evolution of the North African domain was controlled by the Late Triassic-Jurassic break-up of the supercontinent Pangaea, resulting in the opening of oceanic Basins forming the Western NeoTethys and the central Atlantic (Baudin, 1995) (Fig. 1). 


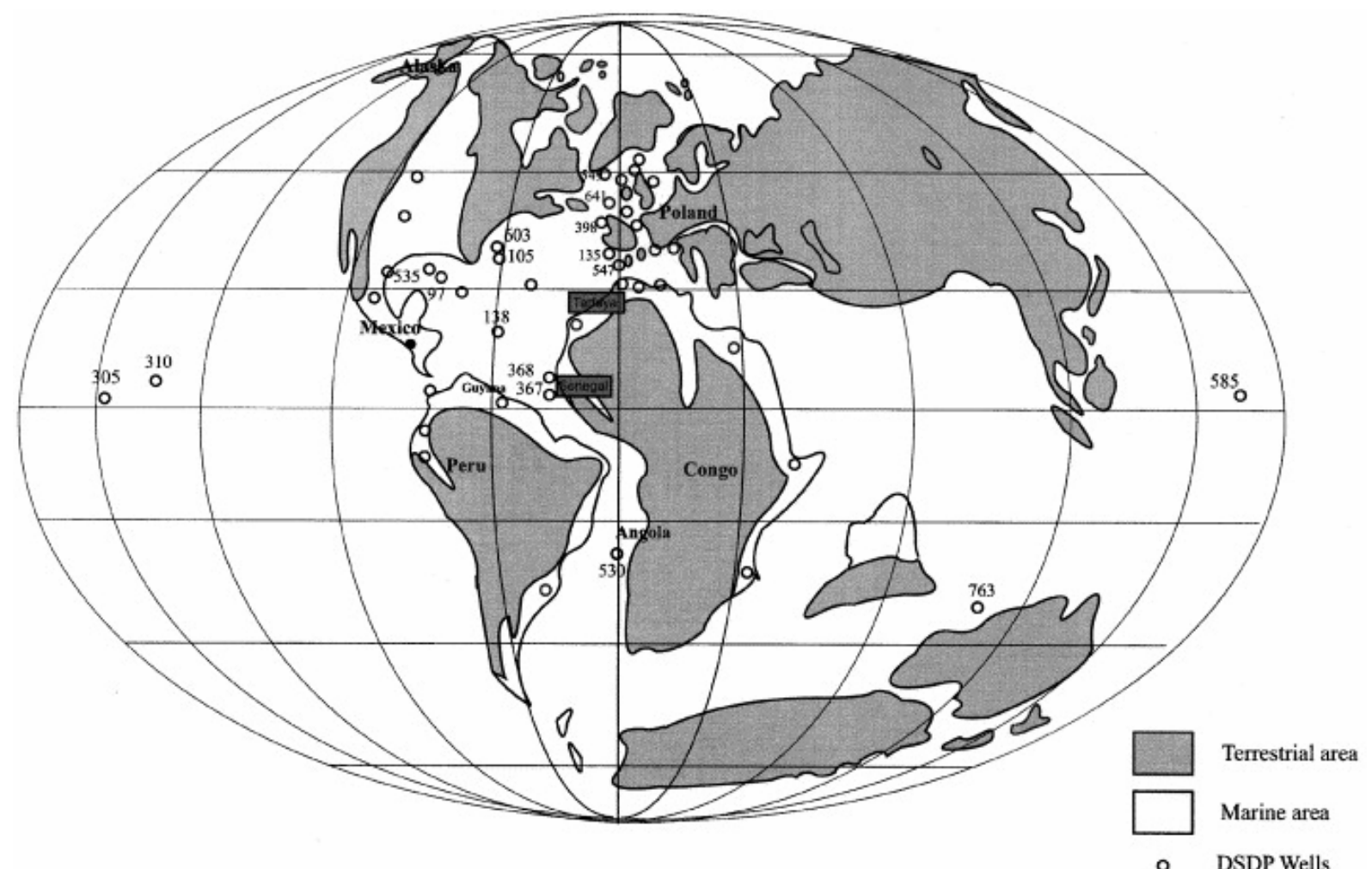

Fig. 1. Paleogeographic map during Cenomanian-Turonian period with DSDP sites according to Schlanger et al. (1987), Herbin et al. (1986) and Arthur et al. (1990).

During the Cenomano-Turonian, the Tethys and the Atlantic Ocean showed sluggish oceanic circulations due to limited connection to the neighbouring oceans (Handoh et al., 1999). These conditions contributed to the development of anoxic bottom waters (Philip et al., 1993 and Philip et al., $\underline{2000}$ ). During the Late Cretaceous, a major oceanic reorganisation occurred when the direction of the deep water circulation reversed from Equator-wards to Pole-wards (Hay, 1982). Accordingly, the establishment of water exchange in response to the deepening and the widening of the Atlantic Ocean had an important impact on the resulting sedimentary facies due to the influence of oxic water currents (Herbin et al., 1986).

\subsection{Senegal Basin}

The Senegal Basin covers an area of $340,000 \mathrm{~km}^{2}$ between 11 and $17^{\circ} \mathrm{N}$ latitudes (Fig. 2) occupying the central part of the large North-Western Africa Basin which extends along Senegal, Gambia, Guinea-Bissau, Mauritania and the Moroccan coastal areas. It opens westward to the Atlantic Ocean and is limited by the Panafrican to Hercynian Mauritanide chain to the east (Villeneuve and Da Rocha Araujo, 1984). This Basin contains more than $14 \mathrm{~km}$ thick Paleozoic to Tertiary sediments. Outcrops are rare and any known stratigraphy is based on deep wells. The thickness of the Meso-Cenozoic sediments partly exceeds $10,000 \mathrm{~m}$ in the western part of the Basin. It consists of transgressive and regressive series: (i) a Jurassic-Lower Cretaceous carbonate platform, (ii) a Cretaceous clastic wedge and (iii), a cap of Tertiary carbonates and shales (Michaud, 1984). 

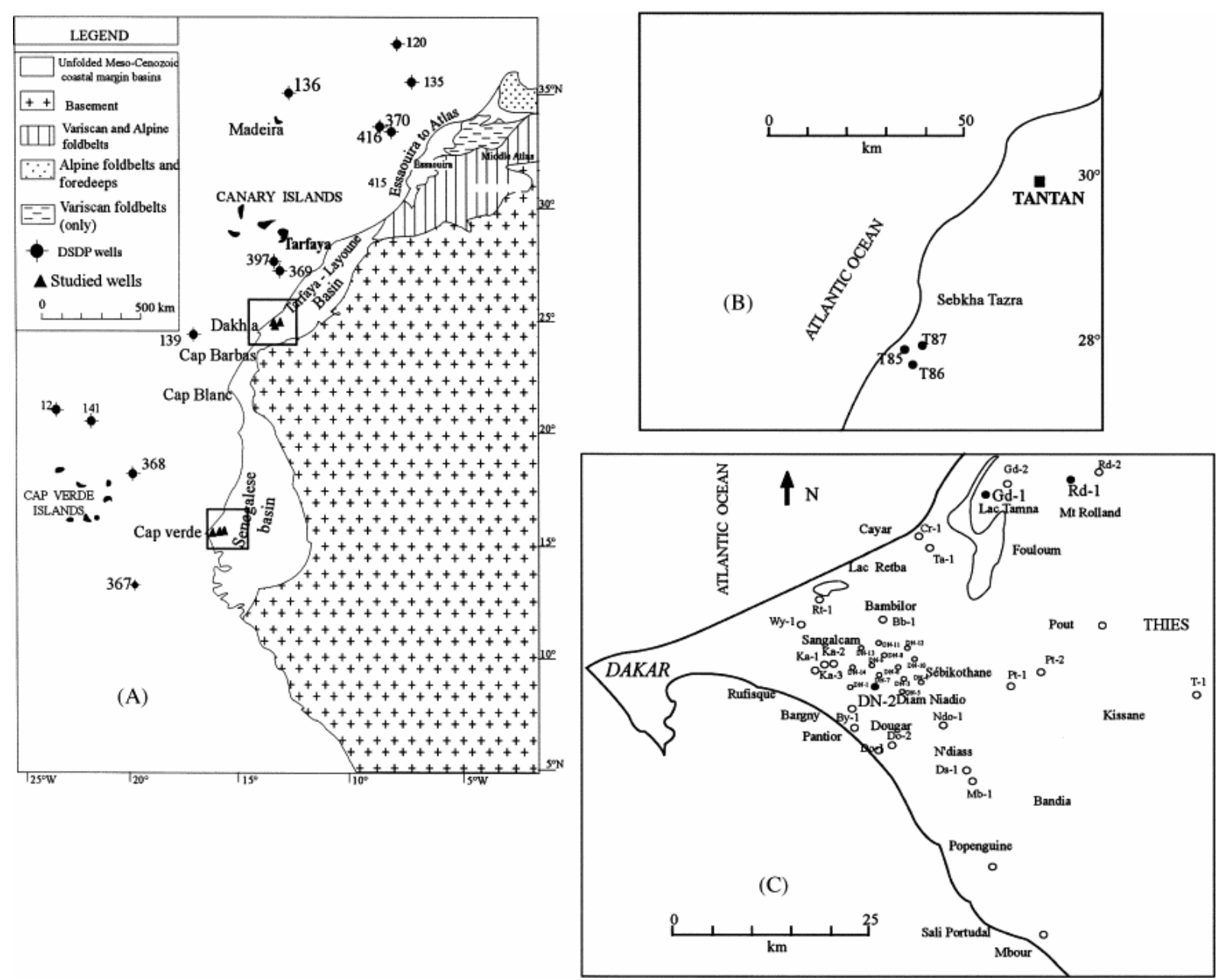

Fig. 2. (A) Map showing generalised geological setting of West African margin and the location of the Senegalese and Tarfaya (Morocco) basins. (B) Location of studied boreholes (T85, T86, T87) within the Tarfaya basin. (C) Location of studied boreholes within the Senegal platform (full circles show the three studied wells, i.e. DN-2, Gd-1, Rd-1).

Three facies characterise the lateral variations of the $\mathrm{C}-\mathrm{T}$ sediments. The first consists of homogenous black shales deposited in the fully marine environment. This facies dominates the western part of the Thies-Diam Niadio area and reaches maximum thickness in Casamance. No well has reached the base of this facies in the study area. However seismic profiles suggest a Basinward increase in thickness. The second facies is characterised by a succession of calcareous and shaly calcareous sediments typical of a transitional neritic environment. The third facies, typical of a sub-littoral to nearshore marine environment, is composed of shales with shaly siltstone intercalations. These sediments become increasingly rich in siltstone towards the shoreline.

\subsection{Tarfaya Basin}

The Tarfaya Basin (Fig. 2) is a tectonically stable Mesozoic Basin, which extends along the southern Moroccan coast between latitudes $27^{\circ} 40^{\prime}$ and $28^{\circ} 40 \mathrm{~N}$ and covers an area of $10,000 \mathrm{~km}^{2}$. It is bounded by the Anti-Atlas Mountains to the North, the 
Precambrian Reguibat Massif in the east and the Atlantic Ocean to the West. Studies based on correlations between deep onshore and offshore (DSDP 369, 397) wells allow to make a synthesis of the stratigraphy and of tectonic evolution of the Basin (Wiedmann et al., 1982). During Triassic times, a synrift continental megasequence $(1000 \mathrm{~m})$ was deposited. The sediments include evaporite horizons followed by sills of dolerite basalts. The post rift phase started with the Jurassic marine transgression, which only affected the northern part of the Basin. Maximum transgression was reached in Late Cenomanian-Early Turonian times. The Cenomanian-Turonian sediments are composed of hemipelagic facies (Leine, 1986). The strata consist of dark brownish and greyish laminated kerogeneous chalks, alternating with non laminated lightly coloured, often nodular limestones having low kerogen content. The same strata were found far toward the east (Well 75) and the west of the basin (Kuhnt et al., 1990 and Kolonic et al., 2002). Kerogen-rich chalks contain abundant fossils (foraminifera tests) and a carbonate matrix mainly composed of coccoliths and micrite (Leine, 1986 and El Albani et al., 1999).

\section{Material and methods}

In the Tarfaya Basin, 94 core samples were obtained from three wells (T85, T86 and T87) (Fig. 2) drilled in the western part of the Sebkha Tazra anticline (Fig. 2). Palaeontological investigations attribute them to Upper Cenonamian-Lower Turonian age (Leine, 1986) according to upper Rotalipora cushmani to lower Whiteinella archaeocretacea biozone (Kuhnt et al., 2001). Concerning the Senegal Basin, 115 samples of drill cuttings were collected from three wells (DN-2, Gd-1, Rd-1) (Fig. 2) which penetrated one of the main facies of the $\mathrm{C}-\mathrm{T}$ succession in the area (NzoussiMbassani et al., 2003). DN-2 corresponds to distal environment, while Rd-1 represents the proximal one.

\subsection{Bulk geochemical analyses}

Total Organic Carbon (TOC) contents (wt.\%), Hydrogen Index (HI, mg HC g${ }^{-1} \mathrm{TOC}$ ), Oxygen Index (OI, mg CO $\left.2 \mathrm{~g}^{-1} \mathrm{TOC}\right)$, Tmax $\left({ }^{\circ} \mathrm{C}\right)$ and Petroleum Potential (PI) were determined by Rock-Eval 6 pyrolysis (Espitalié et al., 1977 and Lafargue et al., 1998). The analyses were carried out on $100 \mathrm{mg}$ of crushed sample under standard conditions. The Tarfaya Basin samples were first analysed using Rock-Eval II. However, for a better comparison between both basins, some of these samples were re-analysed with the model 6 device. Elemental analyses have been performed on bulk material with a Leco CNS2000 analyser in order to determine Total C (TC), N and S contents.

\subsection{Microscopic observations}

OM petrographic studies were performed using a Leica DMR XP microscope under different illumination modes: identification and counting of organic constituents (palynofacies) were carried out under transmitted light on total organic matter (TOM) obtained after acid hydrolysis of carbonates and silicates. Specific characterisation (maceral analysis) of land-derived organic particles, i.e. mainly from vitrinite and inertinite groups, was performed on polished sections of OM densimetric concentrates under reflected light and fluorescence. Identifications were made 
following the nomenclatures of Stach et al. (1982) and the International Commission for Coal Petrology procedures (ICCP, 1971). Random vitrinite measurements $(\mathrm{Rr}$ expressed in \%) were made on the same densimetric concentrates under reflected light using a $\times 50$ oil immersion objective (ICCP, 1971).

The microtexture of selected samples showing geochemical and sedimentological contrasts was studied using a Scanning Electron Microscope (SEM, Hitachi S4200 apparatus) in backscattered electron (BSE) mode combined with energy dispersive $X$-ray spectrometry (EDS). The obtained imaging depends on atomic number $(Z)$ contrasts between the different constituents of the sample, i.e. organic matter and mineral matrix. Investigations were carried out both on polished sections of bulk rocks and of palynofacies residues, previously coated with carbon, with an accelerating voltage of $15 \mathrm{kV}$.

\subsection{Flash pyrolysis-gas chromatography/mass spectrometry (Py-GC- MS)}

The kerogens used for flash pyrolysis-gas chromatography/mass spectrometry analyses were isolated by $\mathrm{HCl} / \mathrm{HF}$ treatment according to the Durand and Nicaise (1980) method. Py-GC-MS analyses were carried out on a Thermofinnigan GCQ TRACE gas chromatography-mass spectrometer equipped with Ficher GSG pyrolysis unit set at $300{ }^{\circ} \mathrm{C}$.

The samples were applied to a ferromagnetic wire with a Curie temperature of 650 ${ }^{\circ} \mathrm{C}$. Pyrolysis is a thermal degradation in an inert atmosphere which generates products with different weights depending on the temperature of pyrolysis and the type of molecular bounds within the macromolecular network. Only $10 \%$ of the pyrolysed products can be analysed by Py-GC-MS. However, NMR and other studies have shown that structural information which can be recovered is, in most cases, representative of bulk material subjected to pyrolysis (Gelin, 1996, Larter and Horsfield, 1993, Horsfield, 1989 and Goth et al., 1988). Even if a precise chemical structure of the macromolecules involved cannot be elucidated by Py/GC/MS, the structural elements in the pyrolysis products can still provide information concerning the origin and the preservation state of sedimentary OM. In this study, pyrolysis products generated between 300 and $650{ }^{\circ} \mathrm{C}$ were analysed by Py-GC-MS according to the following oven temperature program: $40{ }^{\circ} \mathrm{C}$ during $2 \mathrm{~min}$, then $40-$ $100{ }^{\circ} \mathrm{C}$ at $30^{\circ} \mathrm{C} / \mathrm{min}, 100^{\circ} \mathrm{C}-300^{\circ} \mathrm{C}$ at $3^{\circ} \mathrm{C} / \mathrm{min}$, and finally $30 \mathrm{~min}$ hold at $300^{\circ} \mathrm{C}$. Helium was used as a carrier gas. Separation was achieved using a fused silica capillary column $(30 \mathrm{~m} \times 2.5 \mathrm{~mm})$ with $0.25 \mathrm{~mm}$ of stationary phase. The mass spectrometer operated at $70 \mathrm{eV}$ in the electron ionisation mode with a mass range of $\mathrm{m} / \mathrm{z}$ 50-650. 


\section{Results}

\subsection{Senegal Basin}

\subsubsection{Petrographic and bulk geochemical characteristics}

C-T sediments are characterised by low to moderate TOC contents, which does not exceed $4 \%$ (Fig. 3D). HI values are generally low (<300 $\left.\mathrm{mg} \mathrm{HC} \mathrm{g}^{-1} \mathrm{TOC}\right)$ except in some samples originating from the distal part of the Basin. When plotted in a $\mathrm{HI} / \mathrm{OI}$ diagram (Espitalié et al., 1977), the data points are mainly located in the type III OM field (Fig. 3B) thus suggesting an $\mathrm{OM}$ of predominant terrestrial origin (Tissot and Welte, 1984 and Bordenave, 1993). Nevertheless, the high values observed toward the distal part of the Basin indicate marine OM influences. $\mathrm{C} / \mathrm{N}$ ratios also depend on depositional area. In the proximal areas they are generally higher than 10 in contrast to the distal part where some intervals present $\mathrm{C} / \mathrm{N}$ values lower than 10 (Fig. $3 \mathrm{C}$ ). High $\mathrm{C} / \mathrm{N}$ ratios could indicate terrestrial $\mathrm{OM}$ precursor, but should normally not be interpreted separately for OM source characterisation because of possible alteration impact. S/C ratio values are generally lower than 0.36 (Fig. $3 \mathrm{D})$, thus suggesting that the deposition mostly occurred under medium oxic conditions (Raiswell and Berner, 1985 and Morse and Berner, 1995).

As illustrated in a HI-Tmax diagram and by reflectance values, the studied $\mathrm{C}-\mathrm{T}$ series have reached a degree of thermal evolution globally corresponding to the first part of the oil window, i.e. from its onset to its middle part. Such a moderate maturity suggests a limited thermal alteration of OM quality, e.g. depicted by Hydrogen Index values (Fig. $3 \mathrm{~A})$.

Two samples originating from the proximal (Rd-1) and distal area (DN-2) (Fig. 2), respectively, were selected for Scanning Electron Microscopic (SEM) observations. No major distinction in OM distribution has been made between these two samples. In both cases, the OM shows two main morphological features. Firstly, it occurs as thin laminated bands interbedded within the mineral matrix. In the second case, the $\mathrm{OM}$ occurs as rounded to subrounded structures/particles finely dispersed/disseminated in the mineral matrix. 

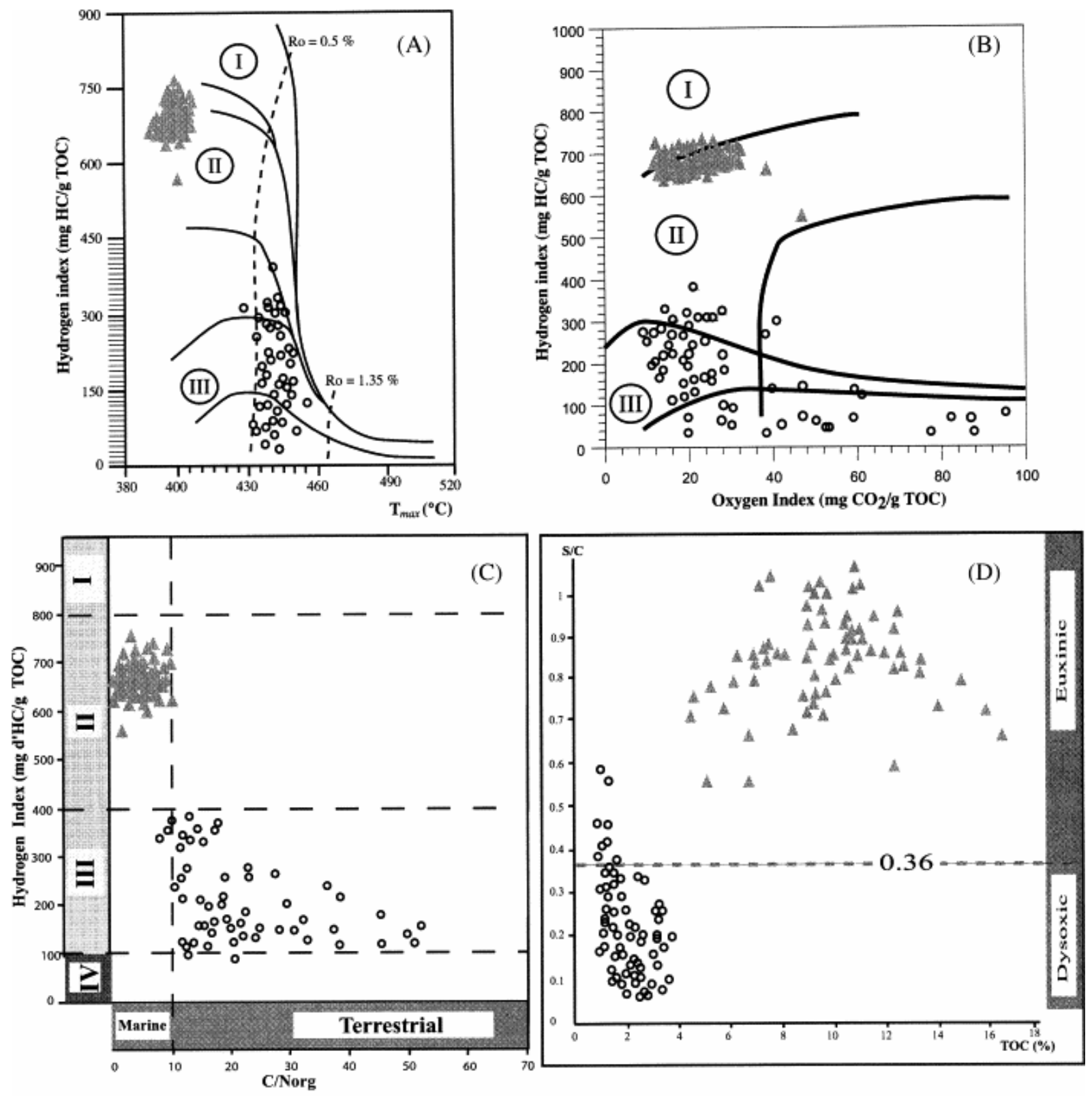

4. Tarfaya samples

- Senegal platform samples

Fig. 3. Bulk geochemical characteristics of studied samples. HI-Tmax diagram (A); HI vs. Ol diagram (B); total organic carbon (TOC) and nitrogen ratio vs. HI (C); sulphur and carbon ratio vs. TOC (D).

EDS microanalysis (Fig. 4) shows that, unlike the particulate OM (Fig. 4B), the laminated $\mathrm{OM}$ systematically presents sulphur enrichment (Fig. 4A). Such results suggest that (i) sulphurisation reaction does not affect all of OM particles and/or (ii) particulate and laminated $\mathrm{OM}$ do not have the same origin. 

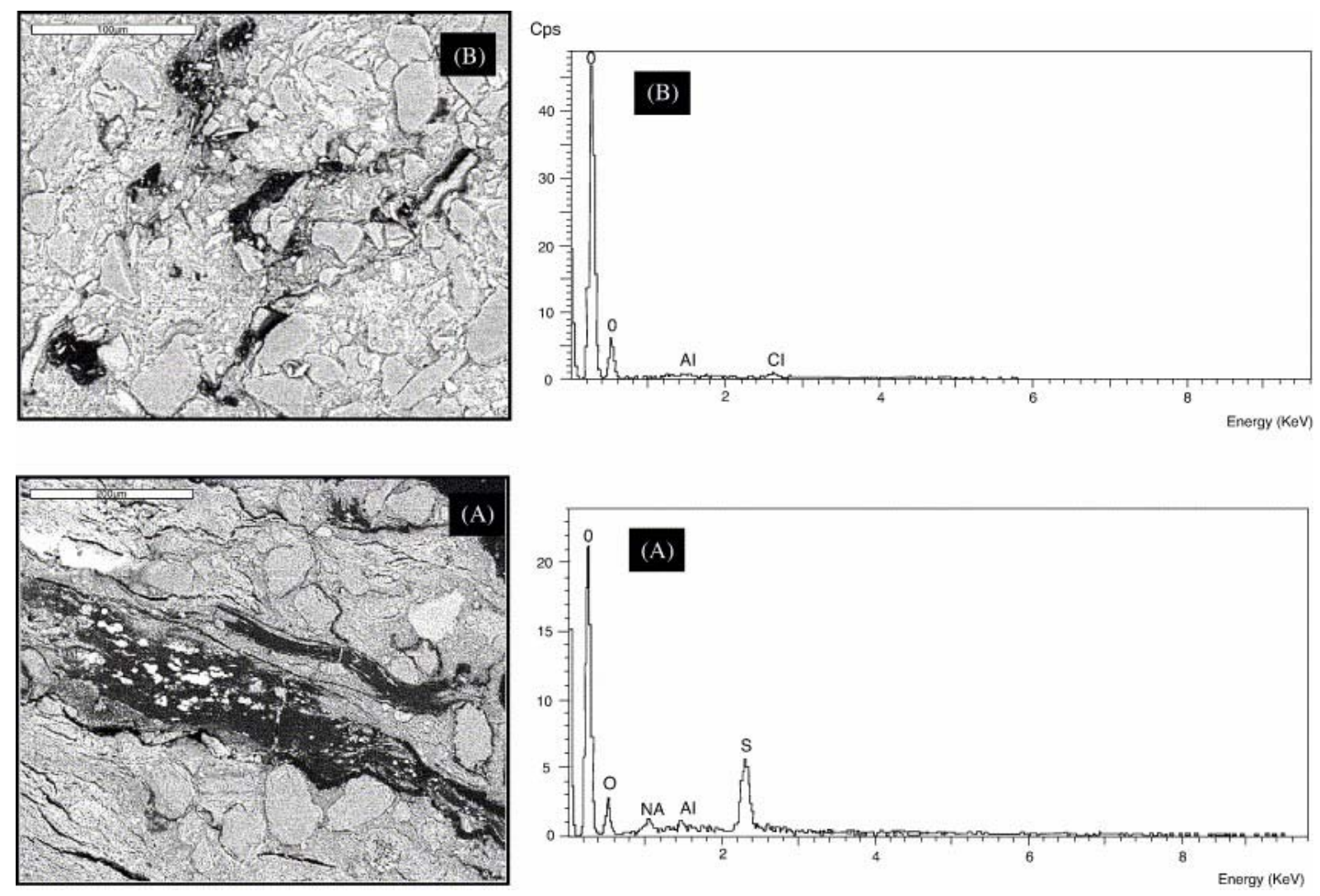

Fig. 4. SEM images of Senegal samples showing two OM morphological features with corresponding EDS analyses: (A) thin laminated bands with sulphur enrichment; (B) dispersed OM without sulphur presence.

The mineral matrix is dominated by $\mathrm{Al}, \mathrm{Fe}, \mathrm{K}, \mathrm{Si}$ while $\mathrm{Ca}$ is rare (Fig. $5 \mathrm{~A}$ ). The notable presence of Titanium indicates terrigeneous influences (Latimer and Filippelli, 2002). Element chemical mapping that have been performed in order to gain a more comprehensive view of elemental distribution, mostly confirms the association of sulphur either with OM or iron in pyrite (Fig. 5B). 


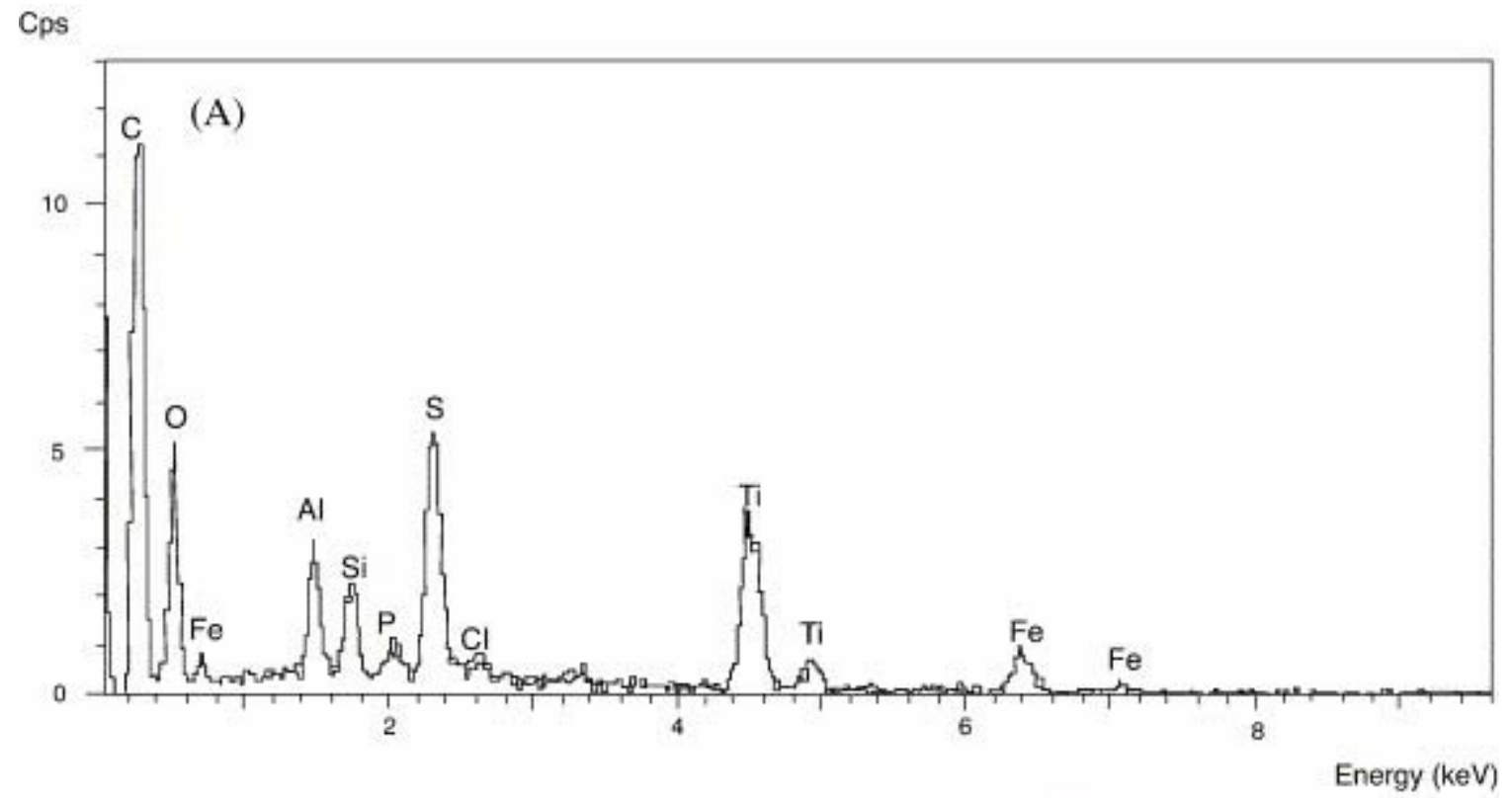

(B)
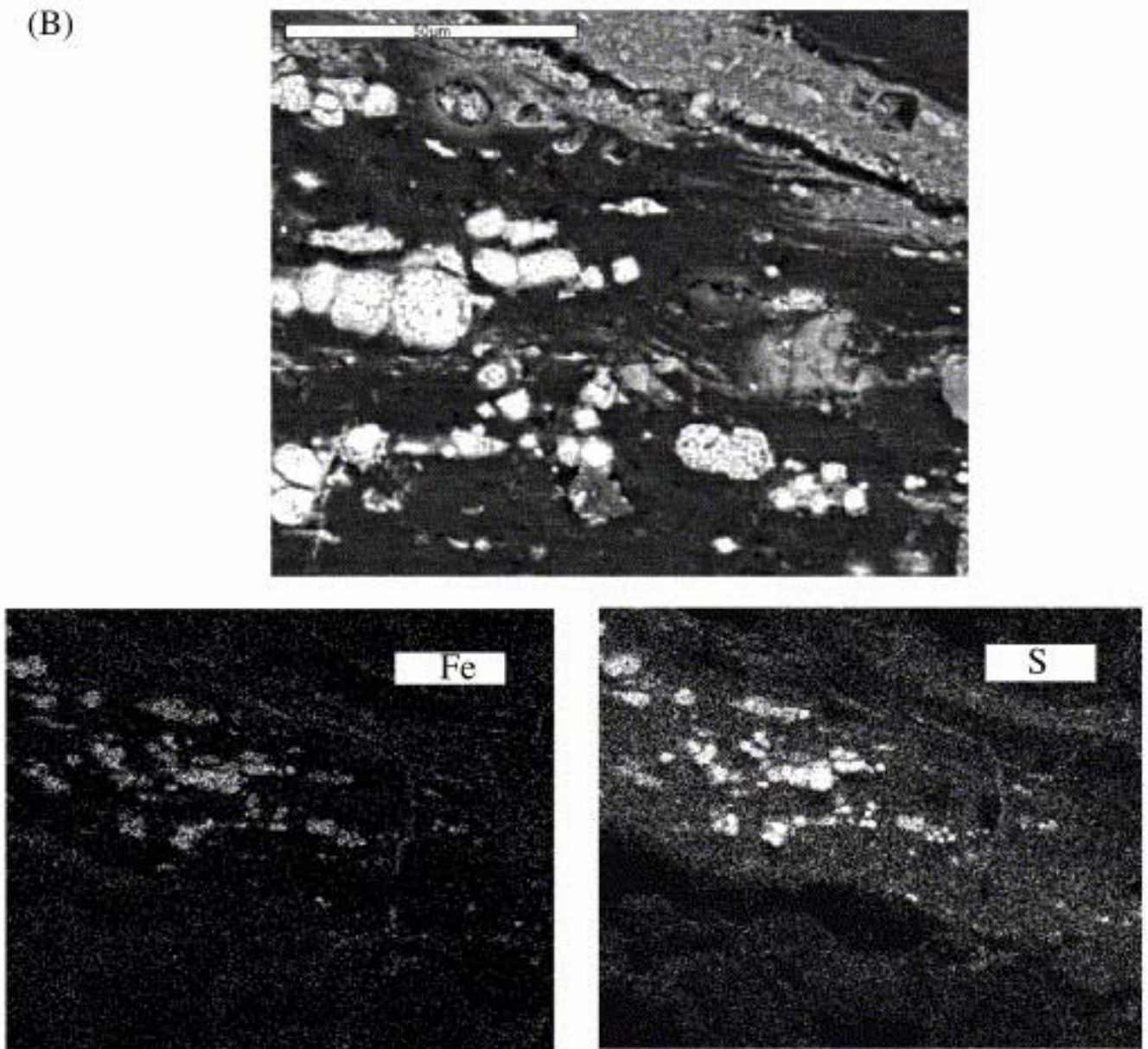

Fig. 5. (A) EDS analysis spectra showing mineral composition of Senegal sediments; (B) an example of elemental $(\mathrm{Fe}, \mathrm{S})$ fingerprints of Senegal samples. 


\subsubsection{Molecular organic geochemical data}

The distributions of the major classes of compounds found in the pyrolyzates can be appreciated in the chromatograms displayed in Fig. 6. These latter ones comprise alkylbenzenes, $n$-alkanes and alkylnaphthalenes (Table 1 and Table 2). There is a slight predominance of alkylbenzene compounds, which show similar distribution in the proximal and the distal Senegal areas. Ethylbenzene is the dominant alkylbenzene compound. The occurrence of these compounds in the pyrolysates could result from the cyclisation and further aromatisation of primary linear functionalised lipid precursors such as fatty acids and fatty alcohols (Largeau et al., 1986 and Derenne et al., 1990).

Table 1. : Alkylbenzenes identified in Senegal samples

\begin{tabular}{|l|l|}
\hline Peak & Compounds \\
\hline 1 & Methyl benzene \\
\hline 2 & 1,2 Dimethylbenzene \\
\hline 3 & Ethylbenzene \\
\hline 4 & 1 -Ethyl-3 methylbenzene \\
\hline 5 & 1,3 Dimethylbenzene \\
\hline 6 & 1-Methyl -3 ethylbenzene \\
\hline 7 & 1-Ethlyl -2 methlybenzene \\
\hline 8 & Propylbenzene \\
\hline
\end{tabular}

Table 2. : Naphthalene identified in Senegal samples

\begin{tabular}{|l|l|}
\hline Peak number & Compounds \\
\hline 1 & Naphthalene \\
\hline 2 & Methylnaphthalene \\
\hline 3 & Dimethylnaphthalene \\
\hline 4 & Trimethylnaphthalene \\
\hline 5 & Ethylnaphthalene \\
\hline
\end{tabular}



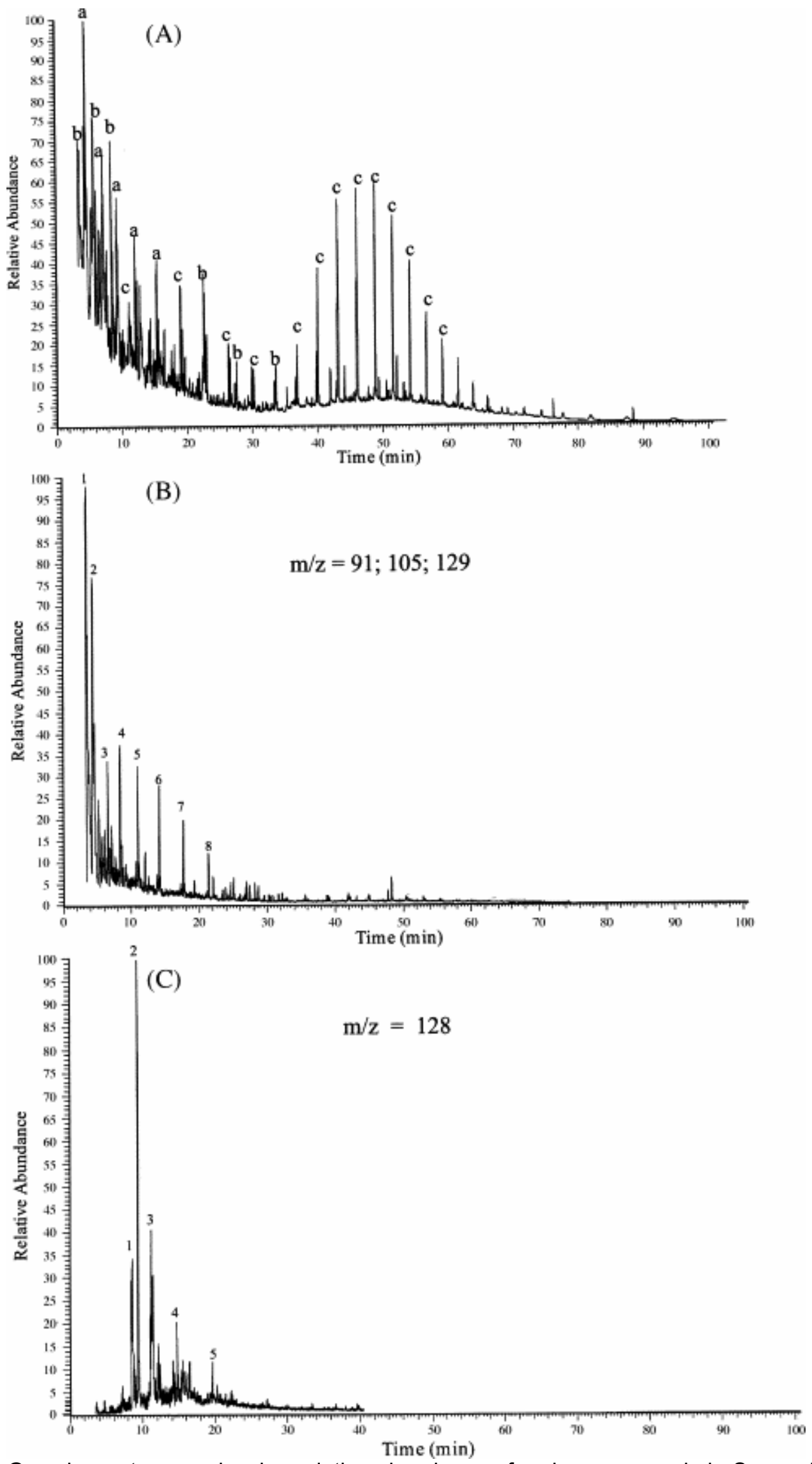

Fig. 6. (A) Gas chromatogram showing relative abundance of major compounds in Senegal samples. (a) Alklylbenzene; (b) naphthalene; (c) alkane. (B) Gas chromatogram showing distribution of the alklybenzene series (see Table 1 for identification). (C) Gas chromatogram showing the distribution of the naphthalene series (see Table 2 for identification). 
The $n$-alkane distributions (Fig. 7) differ between the distal to the proximal sites. The chromatogram from the proximal environment shows a bimodal distribution with a major mode centred on $n \mathrm{C}_{13}$, and the second one on $n \mathrm{C}_{23}$, with no obvious oddover-even predominance in the $\mathrm{C}_{23}-\mathrm{C}_{29}$ range. The classical $n$-alkane bimodal distribution in sample pyrolysates indicates a mixed terrestrial and marine-derived OM.
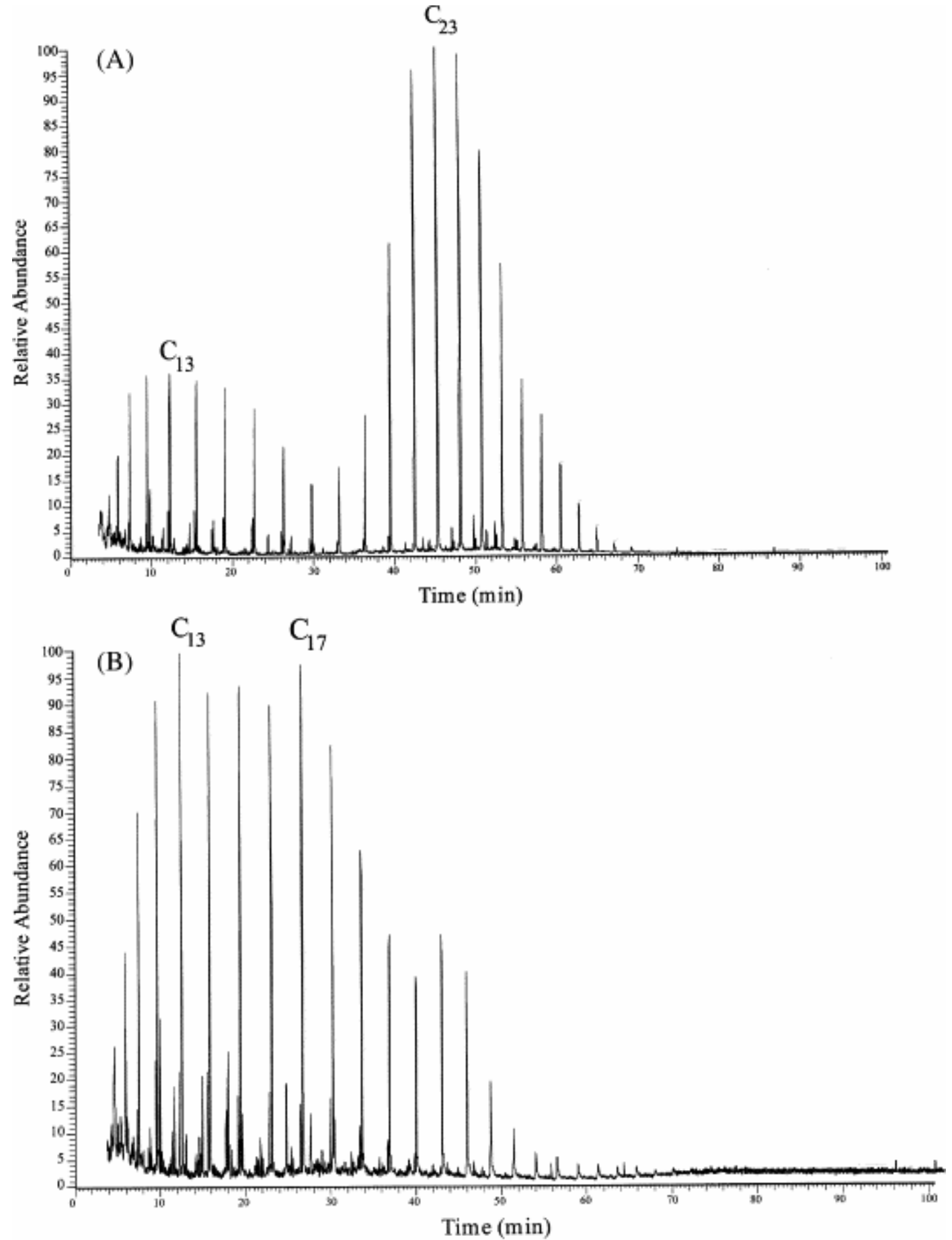

Fig. 7. Gas chromatograms showing $n$-alkane distributions in Senegal samples. (A) Proximal area with bimodal distribution; (B) distal showing unimodal distribution. 
In contrast, the chromatogram from the distal environment is characterised by a unimodal $n$-alkane distribution pattern centred on compounds in $\mathrm{C}_{13}-\mathrm{C}_{17}$, fully representative of a marine-derived OM.

In addition to alkylbenzene compounds, aromatic fractions also comprise alkylnaphthalenes (Fig. 6) and minor alkylphenanthrenes. These compounds, which are particularly well represented in the sample from the proximal environment, confirm the importance of terrestrial OM inputs in this area. Minor amounts of hopanoids $\left(\mathrm{C}_{27}-\mathrm{C}_{31}\right)$, which were identified in the distal area sample (Fig. 8) witness the development of anaerobic bacteria in the deposition environment (Peters and Moldowan, 1993).

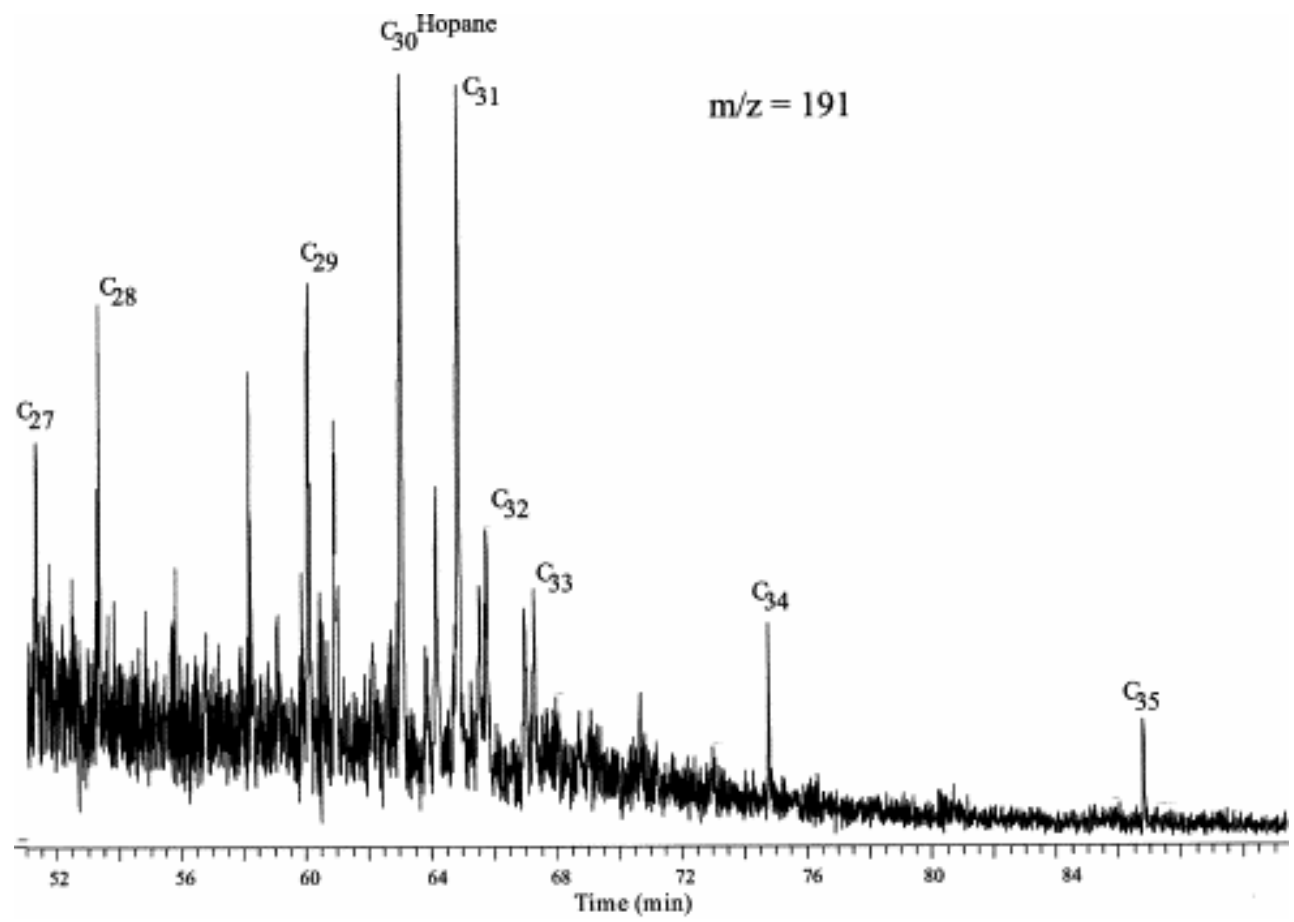

Fig. 8. Gas chromatogram showing the hopane series in distal part of Senegal platform.

\subsection{Tarfaya Basin}

\subsubsection{Petrographic and bulk geochemical characteristics}

Tarfaya sediments show much higher TOC contents than lateral equivalent samples from the Senegal (Fig. 3). As a matter of fact, despite some organic-poor levels (ca. $1.5 \%$ TOC), the mean TOC contents of these sediments is about $7.5 \%$ and can reach up to $16 \%$ in some samples (Fig. $3 \mathrm{D}$ ). HI values vary from 500 to $850 \mathrm{mg} \mathrm{HC} \mathrm{g}^{-1}$ TOC with an average around $600 \mathrm{mg} \mathrm{HC} \mathrm{g}{ }^{-1}$ TOC. According to $\mathrm{HI}$ vs. Ol as well as $\mathrm{HI}$ vs. Tmax diagrams, OM fall close to the maturation pathways typical for type I and type II kerogens (Fig. $3 \mathrm{~A}, \mathrm{~B})$. Such high TOC and HI contents suggest high primary phytoplanktonic productivity and/or favourable OM preservation conditions (Tissot and Welte, 1984).

In this general context, $\mathrm{C} / \mathrm{N}$ ratios lower than 10 (Fig. $3 \mathrm{C}$ ) could be indicative of a notable contribution of nitrogen-rich $\mathrm{OM}$ of marine origin and/or OM alteration. S/C 
ratios (Fig. 3D) greater than 0.36 suggest euxinic conditions in the depositional environment (Raiswell and Berner, 1985 and Morse and Berner, 1995).

Organic particles observed under photonic microscope (Fig. 9) consist mainly of liptinite (90-95\%). The prevailing liptinite groups are alginite and bituminite, while liptodetrinite is seldom observed. Alginite occurs as small (usually less than $20 \mu \mathrm{m}$ long) elongated particles (lamalginite). In marine sediments, alginite and liptodetrinite, respectively, represent the morphologically well and little preserved remains of marine plankton. Bituminite is commonly regarded as a microbial degradation product of more labile OM that can only be (partly) preserved under exceptional conditions such as anoxic bottom waters (Teichmüller, 1982 and Tyson, 1995). Thus, in addition to other indicators such as the abundance of organic carbon and high $\mathrm{S} / \mathrm{C}$ ratios, high proportions of bituminite witness the establishment of anoxic bottom waters during deposition. A subordinate proportion of particles of inertinite or vitrinite of terrigenous origin was also observed. The scarcity of such terrigenous particles indicates low inputs of eroded material in the Basin.
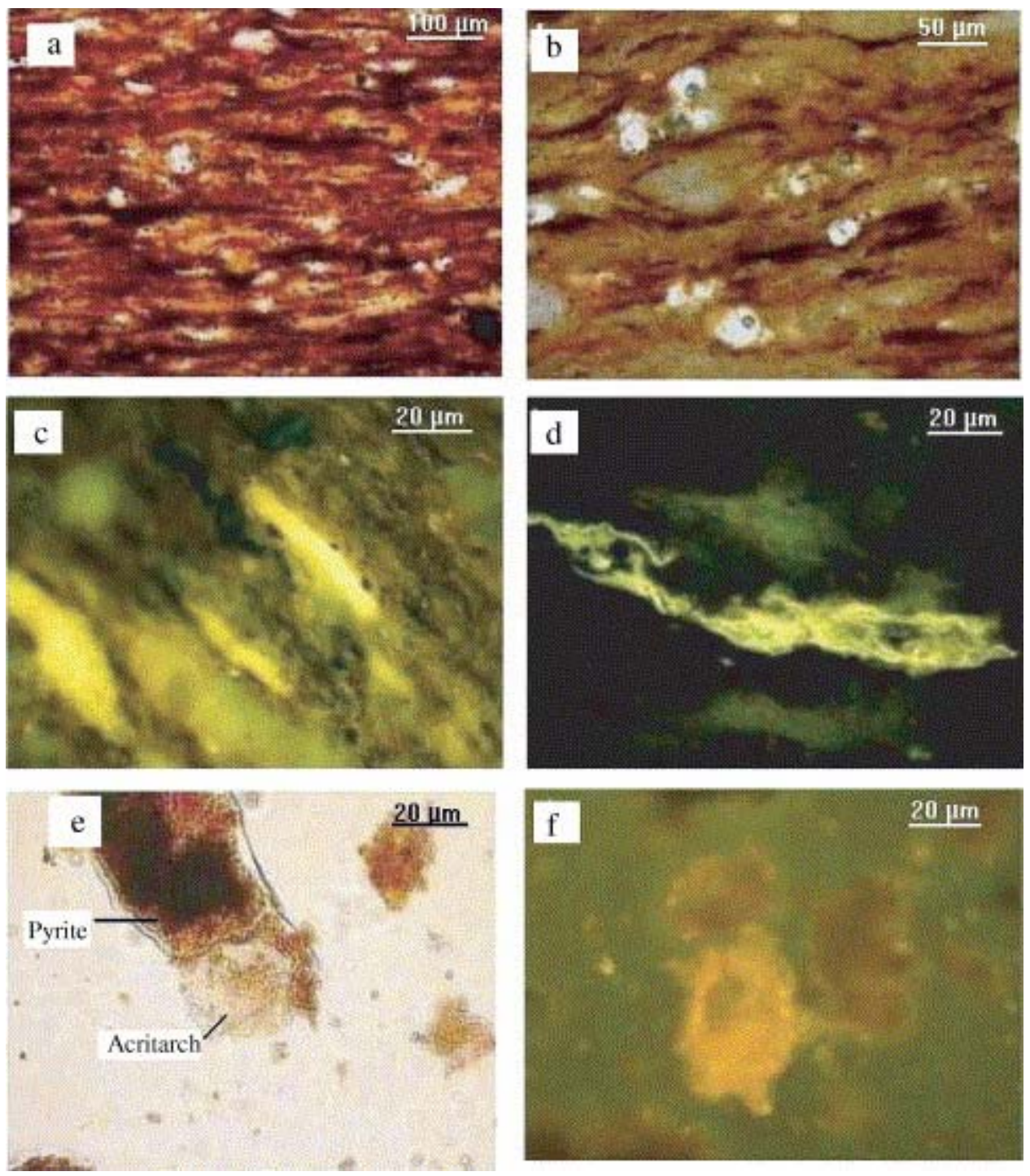

Fig. 9. Photomicrographs illustrating the typical maceral composition of Tarfaya samples. (a) Organicrich sample showing high OM bands. (b) Organic poor sample with dense mineral. (c) and (d) Strong fluorescing alginite. (e) Reddish brown amorphous organic matter (AOM) and (f) fluorescing AOM. 
Under transmitted light (Fig. 9), OM particles isolated by destruction of the mineral matrix (palynofaciès extracts), appear highly dominated by homogenous reddishbrown gelified AOM flakes with frequent inclusions of pyrite flamboids. AOM flakes present variable morphologic appearance and often fluoresces under blue incident light. This fluorescence suggests an oil-prone composition and favourable OM depositional conditions (Lewan, 1986). Rare opaque debris can be identified as inertinite and vitrinite particles. The palynomorphs also contain algal remains and dinocysts and acritarchs. The absence of contrasted OM composition suggests the existence of a single OM source (i.e. marine).

Vitrinite reflectance values determined from the very few particles observed usually vary between $0.3 \%$ and $0.45 \%$. These values are in general agreement with Tmax data which range between $419{ }^{\circ} \mathrm{C}$ and $422{ }^{\circ} \mathrm{C}$ and thus indicate that the $\mathrm{OM}$ is still immature (Fig. $3 \mathrm{~A})$.

SEM investigations show that the microtexture of Tarfaya sediments is similar to that of the Senegal samples, except for the predominance of thick OM laminations in organic-rich sediments. The main difference between the two series concerns sulphur distribution, since EDS microanalyses reveal that the whole OM here is enriched in this element (Fig. 10). This observation points out the role of sulphurisation processes in OM preservation in Tarfaya. The analyses of the mineral fraction (Fig. 11) and elemental X-ray mapping show the predominance of $\mathrm{Ca}$, and in a lesser extent, the presence of carbonate formations.

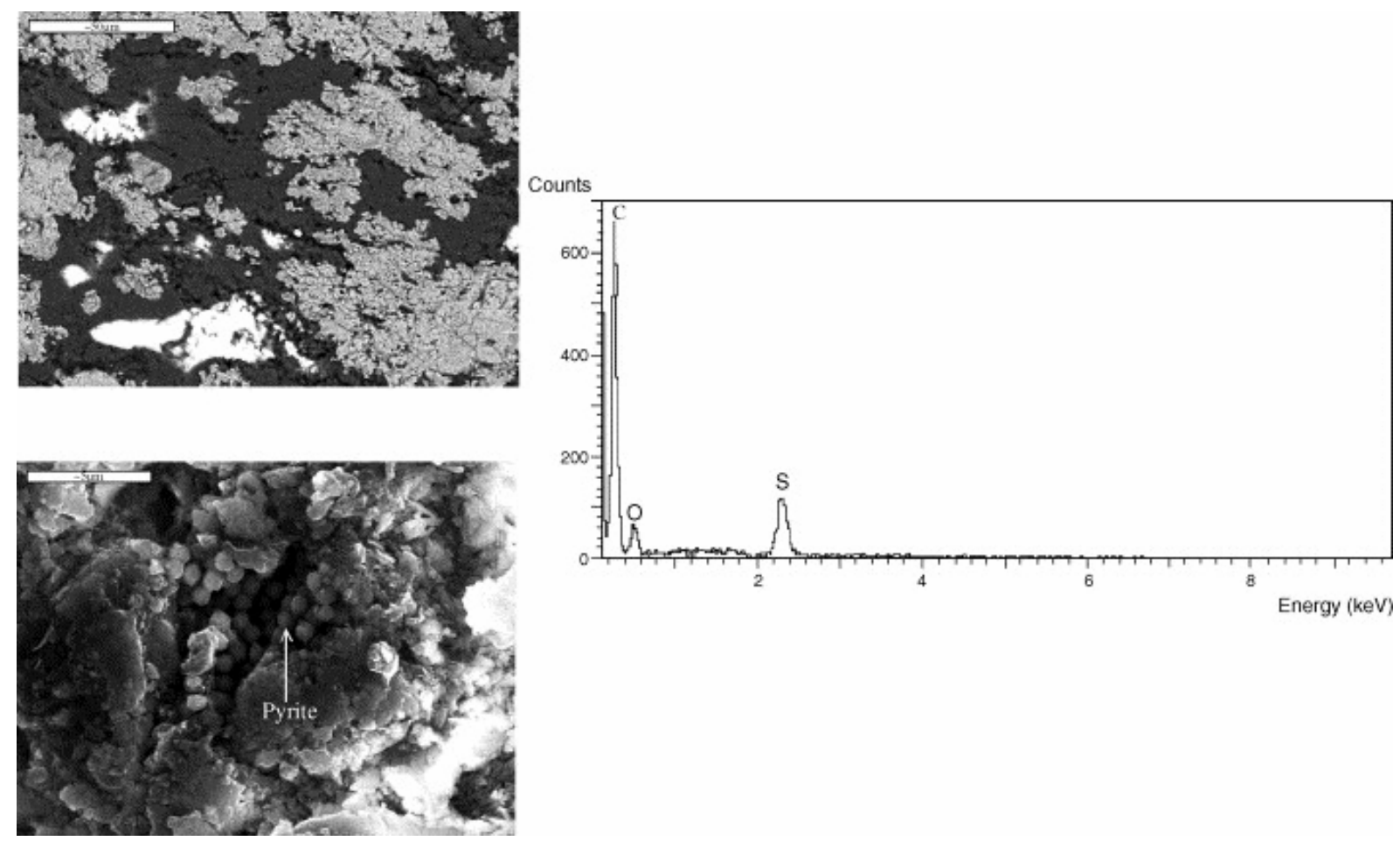

Fig. 10. SEM images of Tarfaya samples showing both OM and mineral matrix relationship and pyrite distribution in mineral matrix. The EDS spectra show the presence of sulphur in OM. 
(A)

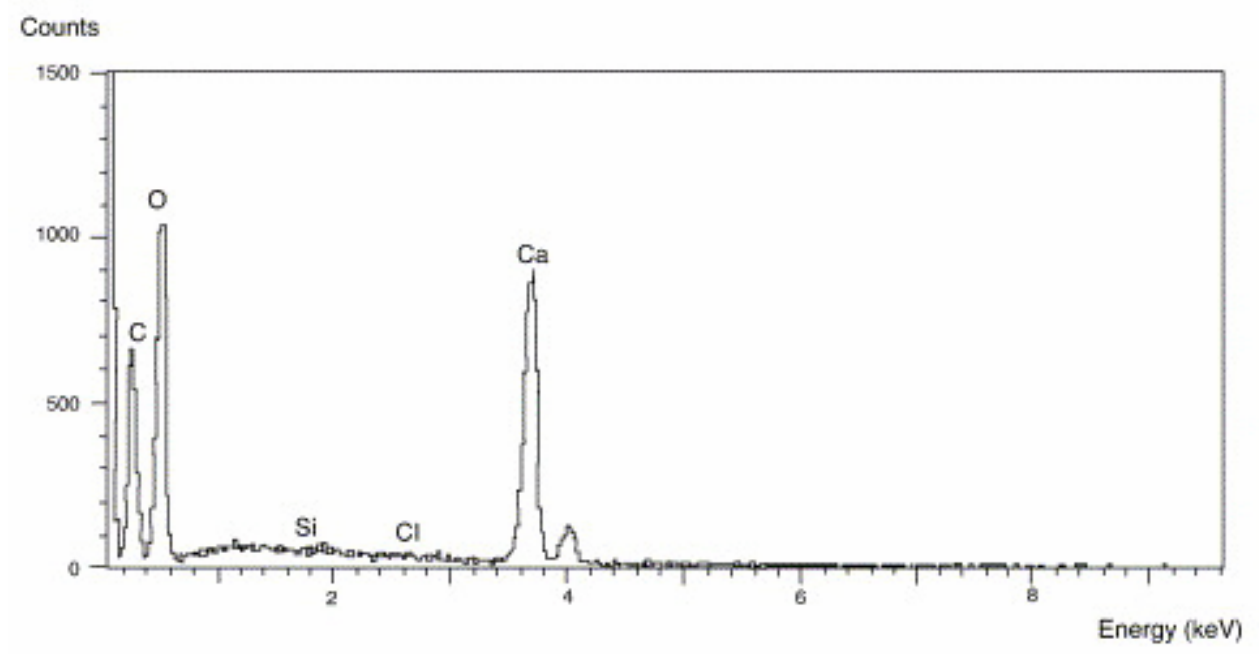

(B)
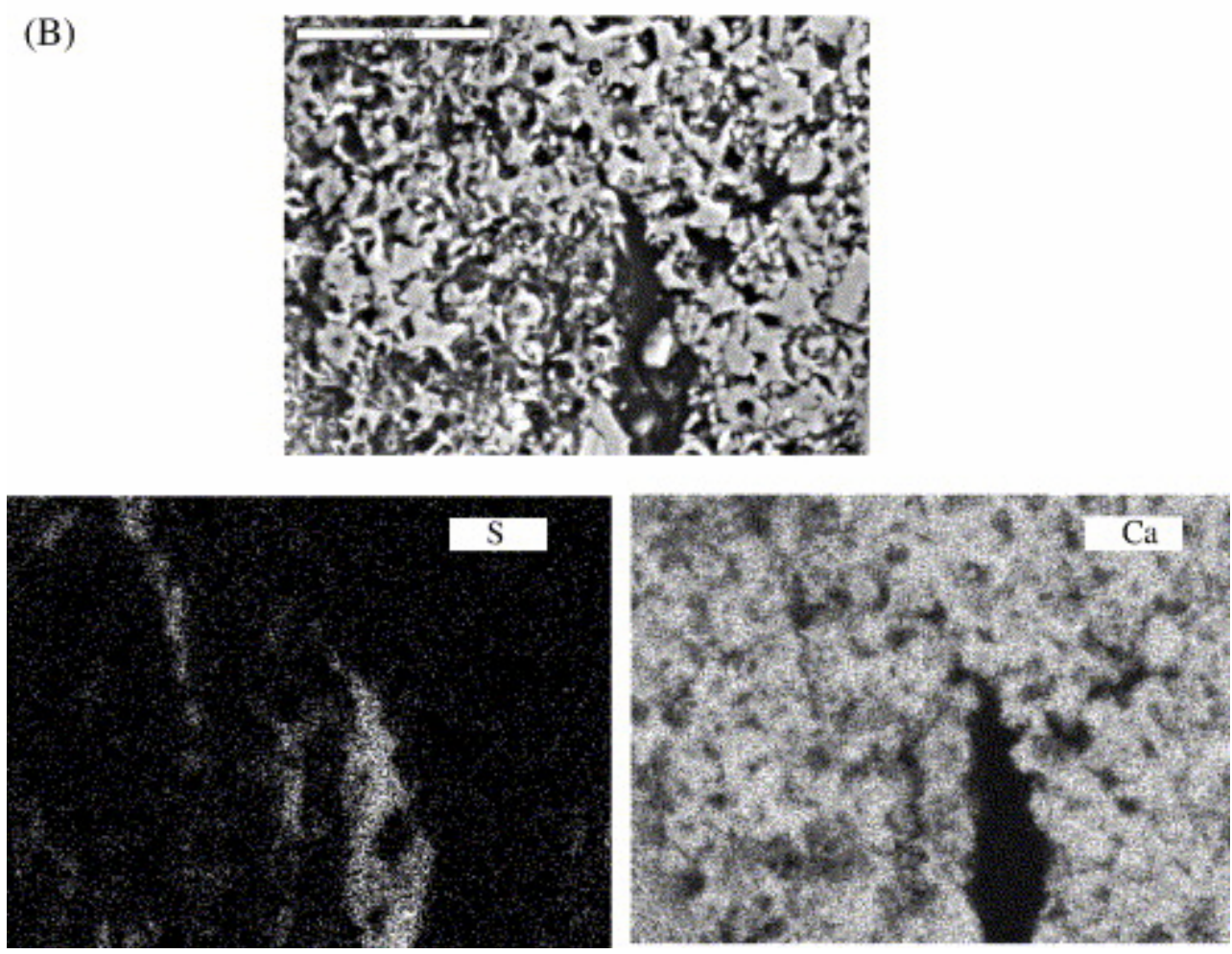

Fig. 11. (A) EDS analysis spectra showing the mineral composition of Tarfaya sediments; (B) an example of elemental $(\mathrm{S}, \mathrm{Ca})$ fingerprints of Tarfaya samples.

\section{Molecular organic geochemical proxies}

The gas chromatogram obtained from samples of the Tarfaya formations are shown in Fig. 12 (Table 3 and Table 4 for identification). The major compounds comprise a long series of alkylthiophenes dominated by 2-ethyl 5-butyl thiophene. A high alkylthiophene content is characteristic of type II-S kerogens (Sinninghé Damsté et al., 1989). According to various authors (e.g. Boussafir et al., 1995, Boussafir and Lallier-Vergès, 1997 and Riboulleau et al., 2000 and references therein), the abundance of sulphur-containing compounds results from the sulphurisation of planktonic lipids and carbohydrates during early diagenesis. Rare benzothiophenes are also observed. 

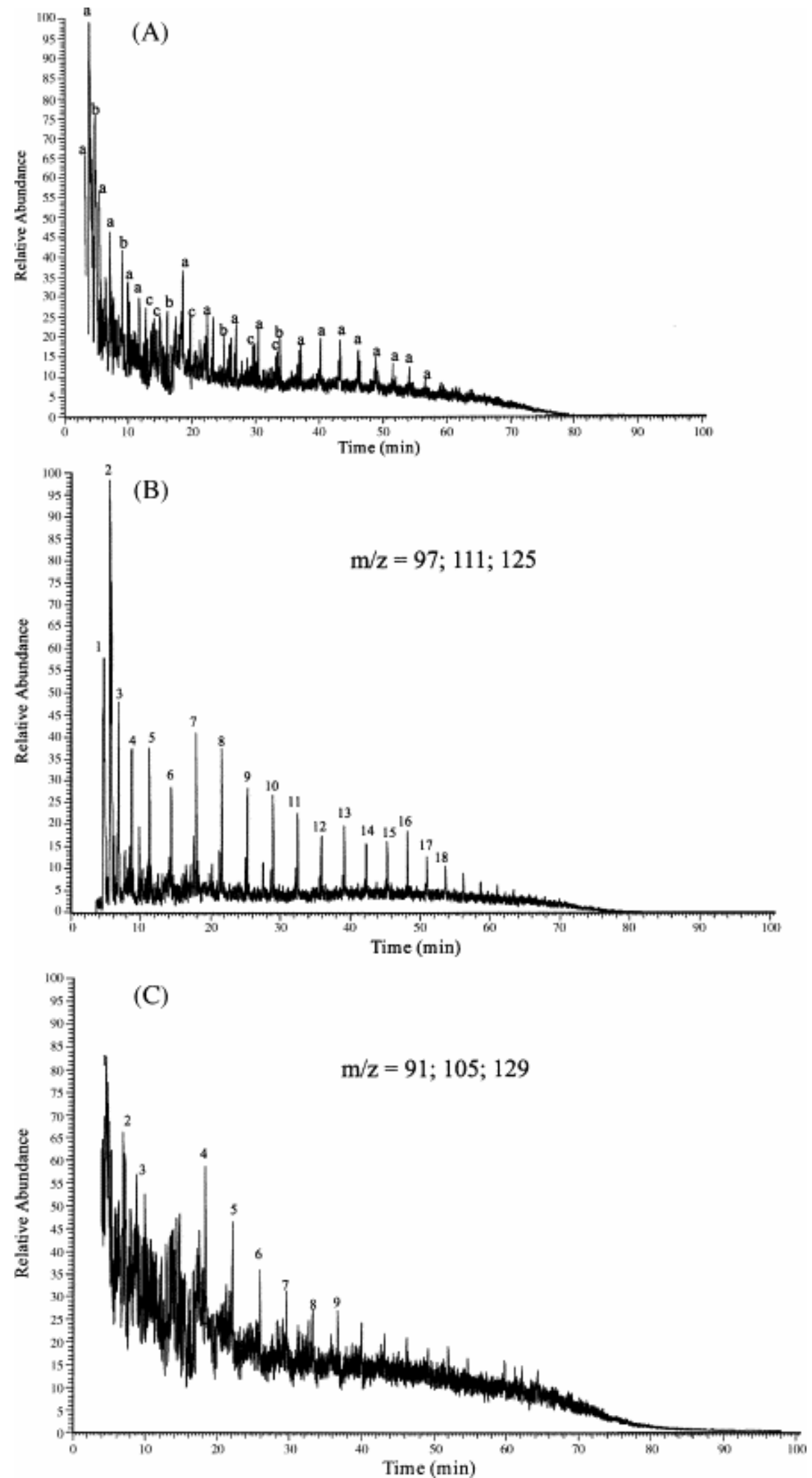

Fig. 12. (A) Gas chromatogram showing relative abundance of major compounds in Tarfaya samples. (a) Alklylthiophene; (b) alkylbenzene; (c) alkane. (B) Gas chromatogram showing distribution of the alklythiophene series (see Table 3 for identification). (C) Gas chromatogram showing the distribution of the alkylbenzene series (see Table 4 for identification). 
Table 3. : Alkyllthiophene identified in Tarfaya samples

\begin{tabular}{|l|l|}
\hline Peak & Compounds \\
\hline 1 & 2-Hexyl thiophene \\
\hline 2 & 2-Ethyl 5-butyl thiophene \\
\hline 3 & 2-Ethyl 5-methyl thiophene \\
\hline 4 & 2-Butyl 5-ethyl thiophene \\
\hline 5 & 2,5 Diethyl thiophene \\
\hline 6 & 2-Pentyl thiophene \\
\hline 7 & 2-Isopropyl thiophene \\
\hline 8 & 2-Butyl thiophene \\
\hline 9 & Benzothiophene \\
\hline 10 & 3-Methyl 2-butyl thiophene \\
\hline 11 & Benzothiophene \\
\hline 12 & 3-Pentyl 3 methyl thiophene \\
\hline 13 & 2-Hexyl 3-ethyl thiophene \\
\hline 14 & 3-Methyl 2-butyl thiophene \\
\hline 15 & Benzothiophene \\
\hline 16 & Propylthiophene \\
\hline 17 & 2,3,5 Trimethylthiophene \\
\hline 18 & 2-Propyl 3-methyl thiophene \\
\hline & \\
\hline
\end{tabular}

The $n$-alkane series (Fig. 13) shows short chain predominance with a maximum abundance at $\mathrm{C}_{13}$. This distribution indicates a predominance of marine $\mathrm{OM}$. Pentacyclic triterpane biomarkers are low abundant or even absent. Hopanoids mainly occur as trisnorhopane (Fig. 13), higher homologues in $\mathrm{C}_{28}-\mathrm{C}_{32}$ are not well developed. Steranes, usually rare in flash pyrolysis products, are not present in high level enough to be identified. 
Table 4. : Alkylbenzenes identified in Tarfaya samples

\begin{tabular}{|l|l|}
\hline Peak & Compounds \\
\hline 1 & 2-Butyl benzene \\
\hline 2 & Ethylbenzene \\
\hline 3 & 1,4 Dimethylbenzene \\
\hline 4 & $1,2,3,4$ Tetramethylbenzene \\
\hline 5 & 1-Methyl 4-methylbenzene \\
\hline 6 & Propylbenzene \\
\hline 7 & Hexylbenzene \\
\hline 8 & 3-Methyl 2-ethylbenzene \\
\hline 9 & 1,2,4-Trimethylbenzene \\
\hline
\end{tabular}

\section{Discussion}

Comparison between Senegal and Tarfaya Basins (Table 5 ) shows large contrast in OM abundance and characteristics. Senegal sediments exhibit mixed OM composition from terrestrial and marine origin. This feature is corroborated by bimodal $n$-alkane distributions, generally high $\mathrm{C} / \mathrm{N}$ ratio values and medium to low $\mathrm{HI}$ values. Unlike Senegal, Tarfaya sediments show nearly homogenous OM composition highly dominated by marine-derived amorphous organic matter (AOM). High $\mathrm{HI}$ values, rather low $\mathrm{C} / \mathrm{N}$ ratio values and $n$-alkane distributions dominated by short-chain compounds, all support the predominance of phytoplanktonic-derived OM. 

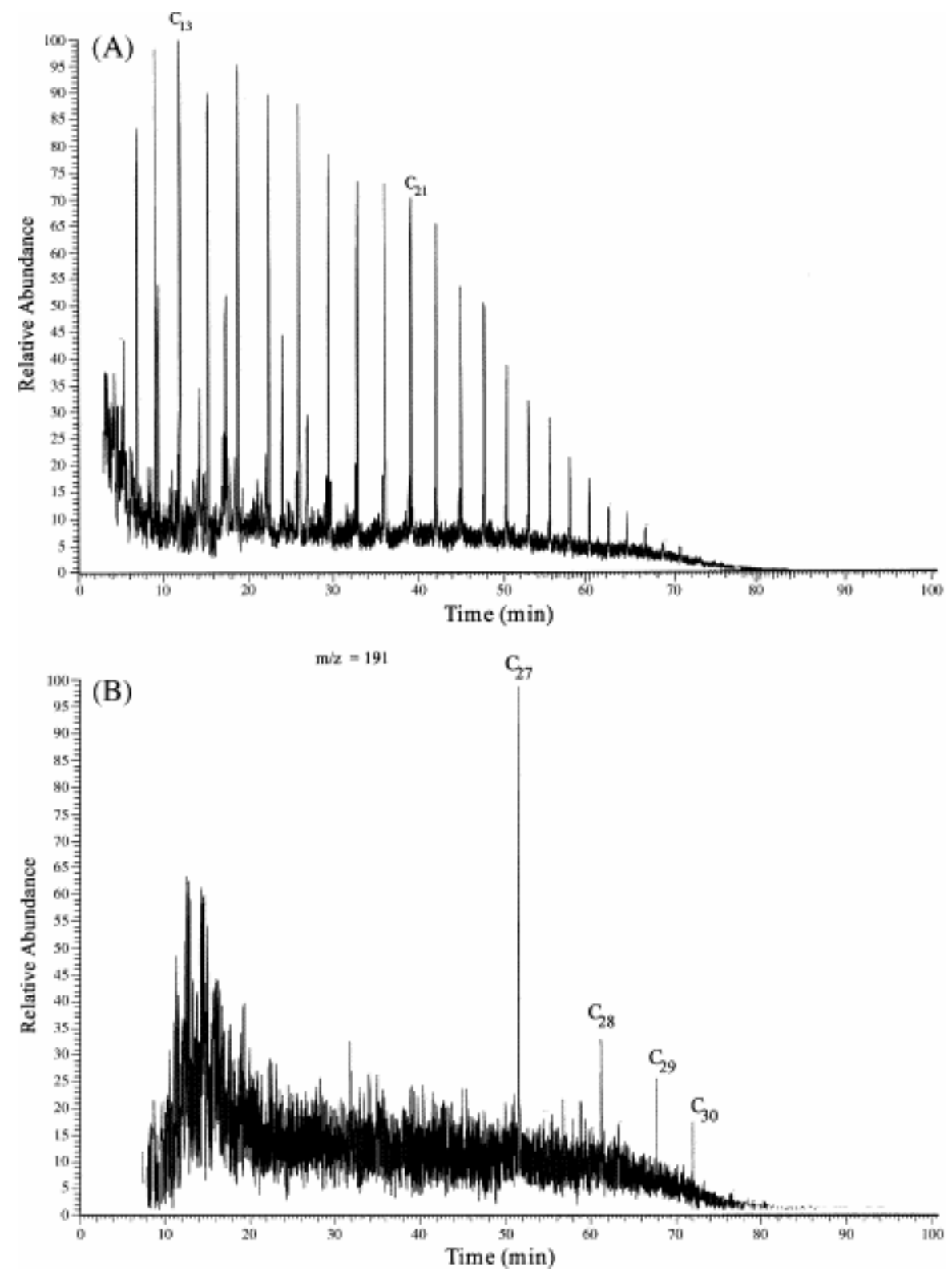

Fig. 13. Gas chromatograms showing $n$-alkane unimodal distribution (A) and hopane distribution (B). 
Table 5. : Synthesised petrographic and geochemical data of Cenomanian-Turonian sediments North-Western Atlantic margin area

\begin{tabular}{|c|c|c|c|c|}
\hline Samples & $\begin{array}{l}\text { Senegal onshore } \\
\text { (shelf } \\
\text { environment) }\end{array}$ & $\begin{array}{l}\text { Tarfaya } \\
\text { (hemipelagic) }^{\text {a }}\end{array}$ & $\begin{array}{l}\text { Senegal offshore } \\
\text { (CM7) } \\
\text { (hemipelagic) }\end{array}$ & $\begin{array}{ll}\begin{array}{l}\text { DSDP } \\
\text { (pelagic) }^{\mathrm{c}}\end{array} & 367\end{array}$ \\
\hline Thickness (m) & $500-2050$ & $100-150$ & 300 & 150 \\
\hline $\begin{array}{l}\text { Sedimentation } \\
\text { rate } \quad(\mathrm{cm} / 1000 \\
\text { year })\end{array}$ & $10-22$ & $1.1-1.7$ & 3.3 & Ca. 0.1 \\
\hline TOC (\%) & $<4 \%$ & $1.5-16 \%$ & $1.27-8.72$ & $10-40 \%$ \\
\hline $\begin{array}{l}\mathrm{HI}(\mathrm{mg} \quad \mathrm{HC} / \mathrm{g} \\
\mathrm{TOC})\end{array}$ & $<400$ & $500-850$ & $152-660$ & $300-900$ \\
\hline Kerogen type & II and III & II & II rarely III & II \\
\hline $\mathrm{C} / \mathrm{N}$ & $>10$ & $<10$ & & \\
\hline $\mathrm{S} / \mathrm{C}$ & $<0.36$ & $>0.36$ & & \\
\hline Liptinite & Very low & $\begin{array}{l}90-95 \% \text { (alginite; } \\
\text { bituminite) }\end{array}$ & & \\
\hline AOM & $>60 \%$ & $\begin{array}{l}\text { Highly } \\
\text { predominant }\end{array}$ & & $\begin{array}{l}\text { Highly } \\
\text { predominant }\end{array}$ \\
\hline Vitrinite I & Notable & Very low & & rare \\
\hline Vitrinite II & Notable & Very low & & rare \\
\hline Inertinite & Notable & Very low & & rare \\
\hline $\begin{array}{l}\text { Molecular } \\
\text { predominance }\end{array}$ & Alkyl benzene & Alkylthiophenes & & Benzothiophene \\
\hline $\operatorname{Tmax}\left({ }^{\circ} \mathrm{C}\right)$ & $435-445$ & $419-422$ & $434-438$ & 396431 \\
\hline$R_{0}$ & $0.3-0.9$ & $0.3-0.4$ & $0.57-0.64$ & 0.24 \\
\hline
\end{tabular}

a This study and Nzoussi-Mbassani (2003).

${ }^{\mathrm{b}}$ Lancelot (1980).

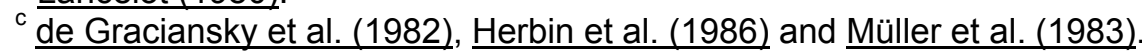

Senegal and Tarfaya Basins also differ on another fundamental factor that is OM preservation conditions. The low $\mathrm{S} / \mathrm{C}$ values and the lack of organo-sulphur compounds observed on the Senegal platform suggest that C-T sediments were deposited in suboxic medium conditions little favourable to OM preservation. These unfavourable conditions were most probably at least partly counterbalanced by a relatively rapid burial due to a high sedimentation rate $(>10 \mathrm{~cm} / \mathrm{ky}$; NzoussiMbassani, 2003) (Table 5). Nevertheless, the latter factor also entailed a notable dilution of the organic inputs. Finally, a poor preservation conditions and high inorganic inputs globally result in the observed low TOC contents. Such features are 
not observed in Tarfaya where high S/C ratio values and the abundance of molecular organo-sulphur compounds typify anoxic depositional conditions whereas a low sedimentation rate (ca. $0.1 \mathrm{~cm} / \mathrm{ky}$; de Graciansky et al., 1982, Herbin et al., 1986 and Müller et al., 1983) excludes a dilution of the organic inputs by the mineral matter. In addition, it is worth underlying that the high sulphur content of Tarfaya sediments is mostly due to S-bearing organic compounds. This is clearly indicative of high reduced sulphur production and incorporation in the OM, during early diagenesis, and thus necessarily of pronounced anoxic medium conditions.

In order to determine a more coherent depositional model for NW Africa margin, the results obtained on Tarfaya and the Senegal Basins are compared to other $\mathrm{C}-\mathrm{T}$ occurrences in the study area (Table 5). The first of these sites is the DSDP 367 well drilled offshore Senegal (Fig. 1) which penetrated a C-T series consisting of alternating black and green claystones deposited in pelagic environment (Lancelot and Seibold, 1977). At this site the sediments show the highest TOC contents (about $40 \%$ ) recorded on the NW African margin, with HI values comprised between 300 to $900 \mathrm{mg} \mathrm{HC} \mathrm{g}^{-1}$ TOC (Herbin et al., 1986). The second site, the CM7 exploration well in the Senegal Basin is also situated offshore Senegal, in southern Casamance. It is representative of a slope or a hemipelagic environment, and thus could be compared to the Tarfaya Basin. The sediments from this site exhibit moderate TOC values (1\% to $8 \%$, Table 5) (Lancelot, 1980).

The comparison of OM data from these two sites with those of Tarfaya and Senegal onshore area (Table 5 ) suggests a northward increase in OM productivity and/or preservation from the shelf (Senegal platform), to the transitional slope (Tarfaya and South Casamance) and the abyssal area (DSDP 367). Such evolution contrasts with the distribution of organic carbon contents observed in major recent and present depositional marine settings (Suess, 1980, Tissot and Welte, 1984 and Bordenave, 1993). Indeed, the OM export flux from the euphotic zone decreases exponentially with depth throughout the water column (Suess, 1980), even in the case of high primary productivity such as in upwelling areas (Bertrand et al., 2003). This process necessarily results in the deposition of OM depleted sediments in deep water settings (abyssal area) compared to shelf areas. The processes that might have influenced OM accumulation in the NW African margin during the $\mathrm{C}-\mathrm{T}$ period are discussed below, and conflict with those observed by many authors in modern high OM sedimentation environments.

\subsection{C-T primary productivity on the NW African margin: comparison with present-day upwelling areas}

The reconstruction of primary palaeoproductivity in general poses a number of problems. One of the main enigmas concerns the source of nutrients that must have supported high OM production. Generally, an abundant supply of nutrients to the surface photic layer can originate from terrestrial environments with riverine transport to the sea and/or directly from the sea, by upwelling currents.

The importance of terrestrial material inputs can be assessed by the rate of sediment accumulation (Waples, 1983). The average rate of sediment accumulation (Table 5 ) during C-T black shale deposition is estimated to ca. $0.1 \mathrm{~cm} / \mathrm{ky}$ for deep areas (DSDP 367; de Graciansky et al., 1982; Herbin et al., 1986, consistently with 
datations provided by Müller et al., 1983) and to ca. 1.1 to $1.7 \mathrm{~cm} / \mathrm{ky}$ at Tarfaya, and around 10 to $22 \mathrm{~cm} / \mathrm{ky}$ for continental shelves (Nzoussi-Mbassani, 2003). In comparison, sediment accumulation in modern high productivity areas such as the Peruvian margin is about $19 \mathrm{~cm} / \mathrm{ky}$ (Oberhänsli et al., 1990 and Wefer et al., 1990) and about 30 to $120 \mathrm{~cm} / \mathrm{ky}$ for the Namibian continental margin (Calvert and Price, 1983). However, the relatively low terrestrial inputs observed in hemipelagic and abyssal areas cannot explain the high OM productivity of these latter sites.

The other possible mechanism for nutrient supply and therefore high bioproductivity in marine area is the upwelling process. The assumption concerning the existence of a palaeo-upwelling regime along the NW African coast during $\mathrm{C}-\mathrm{T}$ was initially mainly based on the existence of high OM contents in the sediments (Herbin et al., 1986). A key to the identification of this process in ancient series requires the identification of some characteristic markers within the sediments. In this respect, recent studies emphasise the distinction between nutrient markers (e.g. nitrates, phosphates, silicates...) and those related to OM production (e.g. diatomaceous ooze, microfossils...) (Romero and Hebbeln, 2003). For example, particular benthic foraminifera assemblages support the existence of palaeoecological conditions specific to upwelling regime in slope to shelf margin environments in NW Africa (Kuhnt and Wiedmann, 1995). Thus, the abundance of Gabonita (typical benthic foraminifera of high productivity areas) in Tarfaya sediments is considered as a proxy of considerable paleoproductivity due to upwelling system (Kuhnt and Wiedmann, 1995).

Other arguments can also be found in modern, supposedly comparable depositional settings. Two areas presently well known to be the site for efficient coastal upwelling responsible of high primary productivity are here considered: the Peruvian margin and the Namibian shelf. Both occur under vigorous costal upwelling system responsible of high primary productivity in the photic zone (Devries and Pearcy, 1982, Calvert and Price, 1983 and Dingle, 1995). On the Peruvian margin, OM-rich sediments are accumulating on the continental shelf (depth lower than $300 \mathrm{~m}$ ) along the eastern Pacific Ocean coast. The sedimentation rate of about $19 \mathrm{~cm} / \mathrm{ky}$ contributes to a maximum sediment organic carbon content of about $12 \%$ (Dingle, 1995). Such values strongly contrast with the low TOC content of the Senegal platform deposits despite a roughly similar sediment accumulation rate. On the Namibian shelf, recent studies have evidenced the presence of OM-rich sediments deposited in hemipelagic and pelagic environment with an average TOC content of 3.5\% (Bertrand et al., 2003). On the platform (i.e. below $150 \mathrm{~m}$ depth) TOC contents reach $9 \%$ in an average, but they locally reach 25\% (Calvert and Price, 1971). Some authors proposed that the abyssal OM-rich sediments might be composed of material redeposited from slope, after having been transported to depth by turbidity currents (Huc et al., 2001 and Stow et al., 2001). This assumption is supported by absence of features characteristic of anoxic environment such as laminations and benthic foraminifers (Giraudeau et al., 2002).

There are some similarities in term of high OM content in deep sea sediments between present sedimentation from Namibia and NW African C-T series. However, in contrast to Namibian sediments, the abyssal black shales investigated in NW Africa exhibit fine laminations and no evidence of bioturbation (Herbin et al., 1986 and Lancelot and Seibold, 1977). Such features are typical for anoxic depositional 
conditions. In addition, the absence of carbonates indicates that these black shales were deposited below the carbonate compensation zone (CCD), in pelagic environment (Lancelot and Seibold, 1977).

Assuming a preservation factor of $2 \%$, Bralower and Thierstein (1984) estimated the primary productivity to ca. $50 \mathrm{~g} \mathrm{C} \mathrm{m}^{-2} /$ year corresponding to the middle Cretaceous North Atlantic black shale. Such a value is markedly lower to that measured in present-day upwelling systems and which amounts to 200-360 g C m (Pedersen and Calvert, 1990).

In light of the above discussion which throws some doubts on the role of upwelling systems in the formation of OM-rich sediments we suggest that this process probably did not control the deposition of C-T sediments on NW African coastal area.

\subsection{Euxinic depositional conditions: role of isorenieratane}

The discovery of isorenieratane in sediments from Cenomanian-Turonian in North Atlantic Ocean (Sinninghé Damsté and Köster, 1998), the Pliocene from Mediterranean Sea (Bosch et al., 1998 and Passier et al., 1999) and recently, in the Tarfaya Basin (Kolonic et al., 2002) shed some new light on the conditions of black shale deposition. This molecule derives from the reduction of isorenieratene, a carotenoid uniquely biosynthesized by the brown-colored strains of photosynthetic green sulphur bacteria (chlorobiaceae). In modern environments like the Black Sea the chlorobiaceae proliferate only in sulphate and sulphide-rich waters below the oxic/anoxic boundary (Repeta, 1993 and Sinninghé Damsté et al., 1993). Their presence in sediments thus strongly suggests that water-column euxinia extended into the photic zone at the time of their deposition (Sinninghé Damsté et al., 1993).

The absence of such a marker in the Senegal platform series suggests the inexistence of Photic Zone Euxinia and corroborates previous studies suggesting global suboxic depositional conditions in this Basin (Nzoussi-Mbassani, 2003). In contrast to Kolonic et al. (2002), we did not directly identify any isorenieratene derivative in the pyrolysates of our Tarfaya samples. However, the $1,2,3,4$ tetramethylbenzene (TMB) molecule found in the alkylbenzene series could be related to the presence of isorenieratene in these sediments (Hartgers et al., 1994). Indeed, the 1,2,3,4 tetramethylbenzene (TMB) could be considered as originating from the $\beta$ cleavage of aromatic carotenoid moieties such as isorenieratene during pyrolysis (Hartgers et al., 1994). Various studies such as in the Western Canada sedimentary Basin (Fowler et al., 1993), in the Bakken Formation (Muscio et al., 1994) and more recently in Holocene series (Aycard et al., 2003) established the possible link of this compound and isorenieratene presence. However, its real diagnostic value depends on alkylbenzene distribution (Hartgers et al., 1994 and Hoefs et al., 1995). More explicitly, Hartgers et al. (1994) considered the abundance of TMB as an indicator of isorenieratene incorporation during early diagenesis, when coupled to the co-occurrence of 1-ethyl-2,3,6-trimethylbenzene. The abundance of TMB in our samples coupled to high content in alkybenzene compounds may strongly link to isorenieratene (Hoefs et al., 1995). The development of an anoxic column can then be regarded as a global phenomenon that affected only deep waters as suggested by similar evidences of anoxic deposition medium found in Tarfaya and Senegal offshore sediments. In this context, the presence of benthic 
fossil suggested by Kuhnt and Wiedmann (1995) could indicate temporary or periodic development of dysoxic and oxic bottom waters (Kening et al., 2004).

\subsection{Depositional model}

The appraisal of Cenomanian-Turonian depositional conditions also requires taking into account the whole Basin evolution since the rifting period. The development of a rifting system such as that initiated by Gondwana break up during Early Cretaceous times, usually results in the development of normal faults bounding downthrown and upthrown sides (Anders and Schlische, 1994). As the faults increase in length and displacement, the system attains a typical half-graben geometry, which results in the formation of many isolated Basins delimited by high accommodation zone (Anders and Schlische, 1994 and Gawthorpe, 1999). The existence of a half-graben system responsible of isolated and rift related Basins has been recognised by numerous authors at the North African margin (Orgeval, 1994). The implication of such a tectonic system for further sediment filling and OM accumulation is investigated here after according to the depositional model summarised in Fig. 14.

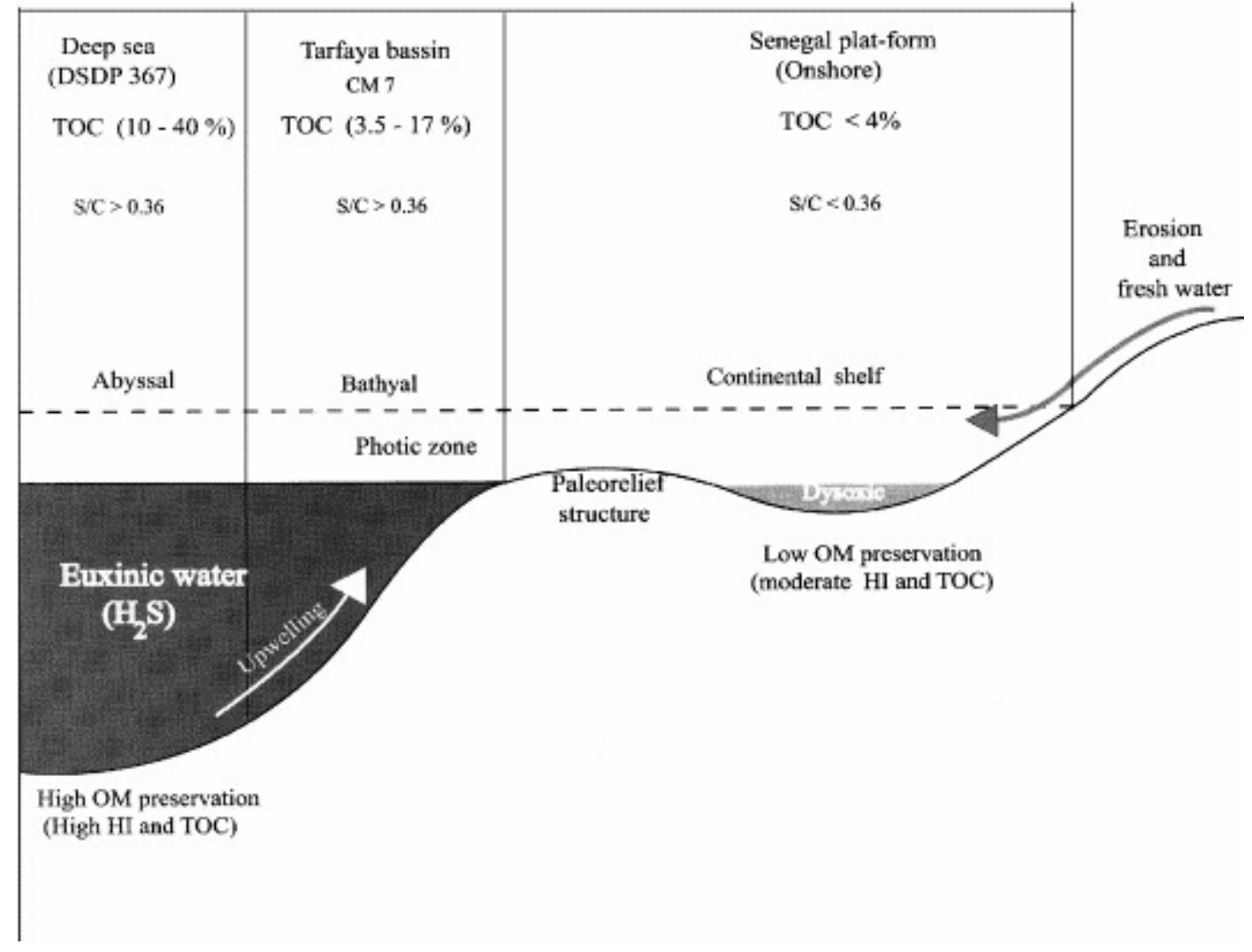

Fig. 14. Paleoceanography and depositional setting during Cenomanian-Turonian time. Note the presence of paleorelief structure between the continental shelf and the bathyal and abyssal environment. This structure restricted water exchange between both depositional settings.

In the general framework of the geological evolution of the whole study area, the different expressions of the so-called C-T anoxic events in the various sites examined led us to suggest that positive palaeorelief features might have isolated deep and anoxic areas from the platform and related suboxic environments. This palaeorelief could have been the relict of the upthrown side/compartment formed 
during rifting. This structural element might have played a key role in limiting exchanges between water bodies and especially in isolating the deep environment (Tarfaya, CM7, DSDP 367) and open shallow marine settings (Senegal shelf). This latter area was characterised by full water circulation and high terrigeneous inputs from hinterlands (siliciclastics, plant material). This detrital material mostly originated from Mauritanides chain to the East and the Reguibat structure to the North.

The described model agrees with some previous observations concerning $\mathrm{C}-\mathrm{T}$ sediment distribution (Orgeval, 1994, Latil-Brun and Lucazeau, 1988, Braun and Beaumont, 1989 and Arthur et al., 1987). Those authors observed that C-T strata in West and North Africa was restricted to a marine facies deposited under minimum water depth and with a distribution that followed palaeoreliefs that existed at that time. This feature appears susceptible to explain the East-West increase in organic carbon content observed from platform to hemipelagic and pelagic environment.

\section{Conclusion}

Organic-rich strata of two North Western African Atlantic Basins were compared through organic petrography and bulk and molecular geochemistry approaches. Each setting revealed specific features of these strata related to depositional environment conditions during Cenomanian-Turonian period. At the scale of North Africa margin those differences may be attributable to paleogeographic configuration and particular geodynamic evolution. The OM-rich sediments were most probably preferentially deposited in isolated and stagnant basins, with oxygen depleted bottom waters. The main factor, which has determined and further increased OM preservation conditions, was certainly the limited communication between southern oxygenated water (opened platform) and northern confined ones (mini-basins). Water stratification, salinity increase, $\mathrm{H}_{2} \mathrm{~S}$ production related to sulphuration processes have certainly contributed to preservation conditions increase. Confined environments are rift related basins originating from horst and graben structures resulting from Atlantic Ocean formation.

One implication of our results is that the occurrence of black shale is a consequence of interaction between particular Middle Cretaceous climate and local factors (paleogeographic conditions). Consequently, behind apparently homogenous facies of black shale sediment, there are many disparities in terms of organic matter composition, depositional environment and preservation conditions. Additionally, primary productivity was certainly not the key factor of C-T black shale deposition. This productivity mainly appeared moderate, especially when compared to presentday upwelling areas.

Finally, according to this study, the conditions that prevailed along the NW African margin during Cenomanian-Turonian times probably differed from those found in the environment of modern upwelling cells. 


\section{Acknowledgements}

The authors would like to thank A.O. Wane and J. Medou from the Senegal Petroleum Corporation for allowing us to access the data and collect the samples. They are grateful to $M$. Hatton and D. Kéravis for technical assistance and are indebted to P.A. Meyers and an anonymous referee for constructive comments on the manuscript.

\section{References}

Anders and Schlische, 1994 M.H. Anders and R.W. Schlische, Overlapping faults, intrabasin highs, and the growth of normal faults, J. Geol. 102 (1994), pp. 165-180.

Arthur et al., 1987 M.A. Arthur, S.O. Schlanger and H.C. Jenkyns, The CenomanianTuronian oceanic anoxia event: II. Paleoceanographic controls on organic matter production and preservation. In: J. Brooks and A.J. Fleet, Editors, Marine and Petroleum Source Rocks, Spec. Publ.-Geol. Soc. Lond. vol. 26 (1987), pp. 401-420.

Arthur et al., 1990 M.A. Arthur, H.C. Jenkyns, H.J. Brumsack and S.O. Schlanger, Stratigraphy, geochemistry and paleoceanography of organic carbon rich cretaceous sequences. In: R.N. Ginsburg and B. Beaudoin, Editors, Cretaceous Resources, Events and Rhythms, Kluwer Academic Publisher (1990), pp. 75-119.

Aycard et al., 2003 M. Aycard, S. Derenne, C. Largeau, T. Mongenot, N. Tribovillard and F. Baudin, Formation pathways of proto-kerogens in Holocene sediments of the upwelling influenced Cariaco Trench, Venezuela, Org. Geochem. 34 (2003), pp. 701-718.

Baudin, 1995 F. Baudin, Depositional controls on Mesozoic source rocks in the Tethys. In: A.-Y. Huc, Editor, Paleogeography, Paleoclimate and Source Rocks, Am. Assoc. Pet. Geol. Stud. Geol. vol. 40 (1995), pp. 191-211.

Bertrand et al., 2003 P. Bertrand, T.F. Pedersen, R. Schneider, G. Shimmield, E. Lallier-Vergès, J.R. Disnar, J. Massias, N. Tribovillard, A.Y. Huc, X. Giraud, C. Pierre and M.T. Vénec-Peyré, Organic-rich sediments in ventilated deep-sea environments: relationship to climate, sea level, and tropic changes, J. Geophys. Res. 108 (2003), pp. 1-11.

Bordenave, 1993 M.L. Bordenave, The sedimentation of organic matter. In: M.L. Bordenave, Editor, Applied Petroleum Geochemistry, Technip, Paris (1993), pp. 1673.

Bosch et al., 1998 H.-J. Bosch, J.S. Sinninghé Damsté and J.W. de Leeuw, Molecular palaeontology of Eastern Mediterranean sapropels: evidence for photic zone euxinia. In: A.H.F. Robertson, K.C. Emeis, C. Richter and A. Camerlenghi, Editors, Proceedings of the Ocean Drilling Program. Scientific Results vol. 160 (1998), pp. 725-735. 
Boussafir and Lallier-Vergès, 1997 M. Boussafir and E. Lallier-Vergès, Accumulation of organic matter in the Kimmeridge Clay Formation (KCF): an update fossilisation model for petroleum source-rocks, Mar. Pet. Geol. 14 (1997), pp. 75-83.

Boussafir et al., 1995 M. Boussafir, F. Gelin, E. Lallier-Vergès, S. Derenne, P. Bertrand and C. Largeau, Electron microscopy and pyrolysis of kerogens from the Kimmeridge Clay Formation, UK: source organisms, preservation process and origin of microcycles, Geochim. Cosmochim. Acta 59 (1995), pp. 3731-3747.

Bralower and Thierstein, 1984 T.J. Bralower and H.R. Thierstein, Low productivity and slow deep circulation in mid-Cretaceous oceans, Geology 12 (1984), pp. 614618.

Braun and Beaumont, $1989 \mathrm{~J}$. Braun and C. Beaumont, A physical explanation of the relation between flank uplifts and the breakup unconformity at rifted continental margins, Geology 17 (1989), pp. 760-764.

Busson and Cornée, 1996 G. Busson and J. Cornée, L'évènement océanique anoxique du Cénomanien supérieur-terminal, Publ.-Soc. Géol. Nord. 23 (1996) (143 pp.).

Calvert and Price, 1971 S.E. Calvert and N.B. Price, Recent sediments of the South West African shelf. In: F.M. Delaby, Editor, Geology of the East Atlantic Continental Margin, Her Majesty's Stationery Office, London (1971), pp. 175-185.

Calvert and Price, 1983 S.E. Calvert and N.B. Price, Geochemistry of Namibian Shelf sediments. In: J. Thiede and E. Duess, Editors, Coastal Upwelling: Its Sediment Record: Part B. Sedimentary Records of Ancient Coastal Upwelling, Plenum Press, New York (1983), pp. 337-375.

Derenne et al., 1990 S. Derenne, C. Largeau, E. Casadevall, J.S. Sinninghé Damsté, E.W. Tegelaar and J.W. de Leeuw, Characterisation of Estonian kukersite by spectroscopy and pyrolysis: evidence for abundant alkyl phenolic moieties in an Ordovician, marine type II// kerogen. In: B. Durand and F. Behar, Editors, Advances in Organic Geochemistry, Pergamon Press, Oxford (1990), pp. 873-888.

Devries and Pearcy, 1982 T.J. Devries and W.G. Pearcy, Fish debris in sediments of the upwelling zone off central Peru: a late quaternary record, Deep-Sea Res. 28 (1982), pp. 87-109.

Dingle, 1995 R.V. Dingle, Continental shelf upwelling and benthic Ostracoda in the Benguela System (south-eastern Atlantic Ocean), Mar. Geol. 122 (1995), pp. 207225.

Durand and Nicaise, 1980 B. Durand and G. Nicaise, Procedures for kerogen isolations. In: B. Durand, Editor, Kerogen, Technip, Paris (1980), pp. 35-53. 
El Albani et al., 1999 A. El Albani, W. Kuhnt, F. Luderer, J.P. Herbin and M. Caron, Palaeoenvironmental evolution of the Late Cretaceous sequence in the Tarfaya Basin (southwest of Morocco). In: N.R. Cameron, R.H. Bâte and V.S. Dure, Editors, The Oil and Gas Habitats of South Atlantic, Spec. Publ.-Geol. Soc. Lond. vol. 153 (1999), pp. 223-240.

Espitalié et al., 1977 J. Espitalié, J.L. Laporte, M. Madec, F. Marquis, P. Leplat, J. Paulet and $A$. Boutefeu, Méthode rapide de caractérisation des roches mères, de leur potentiel pétrolier et de leur degré d'évolution, Rev. Inst. Fr. Pet. 32 (1977), pp. 23-42.

Fowler et al., 1993 M.G. Fowler, L.D. Stasiuk and P.W. Brooks, Middle Devonian oils and sources rocks from western Canada sedimentary Basin, Abstract of presentation given at 1993 GAC-MAC Joint Meeting, Edmonton (1993).

de Graciansky et al., 1982 P.C. de Graciansky, E. Brosse, G. Deroo, J.P. Herbin, L. Montadert, C. Müller, J. Sigal and A. Schaaf, Les formations d'âge crétacé de l'Atlantique Nord et leur matière organique: paléogéographie et milieux de dépôt, Rev. Inst. Fr. Pet. 37 (1982), pp. 275-336.

de Graciansky et al., 1984 P.C. de Graciansky, G. Deroo, J.P. Herbin, L. Montadert, C. Müller, A. Schaaf and J. Sigal, Ocean-wide stagnation episode in the late Cretaceous, Nature 308 (1984), pp. 346-349.

Gawthorpe, 1999 R.L. Gawthorpe, Role of fault interactions controlling synrift sediment dispersal patterns: Miocene, Abu Alaqa group, Suez rift, Sinai, Egypt, Basin Res. 11 (1999), pp. 167-189.

Gelin, 1996 Gelin, F., 1996. Isolation and chemical characterisation of resistant macromolecular constituents in microalgae and marine sediments. PhD thesis, Univ. Utrecht. 139 (147 pp.).

Giraudeau et al., 2002 J. Giraudeau, P.A. Meyers and B.A. Christensen, Accumulation of organic and inorganic carbon in Pliocene-Pleistocene sediments along the SW African margin, Mar. Geol. 180 (2002), pp. 49-69.

Goth et al., 1988 K. Goth, J.W. de Leeuw, W. Püttman and E.W. Tegelaar, Origin of Messel Oil Shale kerogen, Nature 336 (1988), pp. 759-761.

Handoh et al., 1999 I.C. Handoh, G.R. Bigg, E.J.W. Jones and M. Inoue, An ocean modeling study of the Cenomanian Atlantic: equatorial paleo-upwelling, organic-rich sediments and the consequences for a connection between the proto-North and South Atlantic, Geophys. Res. Lett. 26 (1999), pp. 223-226.

Hartgers et al., 1994 W.A. Hartgers, J.S. Sinninghé Damsté, A.G. Requejo, J. Allan, J.M. Hayes, Y. Ling, T.M. Xie, J. Primack and J.W. de Leeuw, A molecular and carbon isotopic study towards the origin and diagenetic fate of diaromatic carotenoids, Org. Geochem. 22 (1994), pp. 703-725. 
Hay, 1982 W.W. Hay, Mesozoic paleo-oceanography of Atlantic and Western Interior Seaway, Am. Assoc. Pet. Geol. Bull. 66 (1982), pp. 568-579.

Herbin et al., 1986 J.P. Herbin, L. Montadert, C. Müller, R. Gomez, J. Thurow and J. Wiedmann, Organic-rich sedimentation at the Cenomanian-Turonian boundary in oceanic and coastal Basins in the North Atlantic and Tethys, Spec. Publ.-Geol. Soc. Lond. 21 (1986), pp. 389-422.

Hoefs et al., 1995 M.J.L. Hoefs, J.D. Van Heemst, F. Gelin, S. Schouten, J.W. de Leeuw and J.S. Sinninghé Damsté, Alternative biological sources of 1,2,3,4 tetramethylbenzene in flash pyrolysate of kerogen, Org. Geochem. 23 (1995), pp. 975-979.

Horsfield, 1989 B. Horsfield, Practical criteria for classifying kerogens: some observations from pyrolysis-gas chromatography, Geochim. Cosmochim. Acta 53 (1989), pp. 891-901

Huc et al., 2001 A.Y. Huc, P. Bertrand, D.A.V. Stow, J. Gayet and M. Vandenbroucke, Organic sedimentation in deep offshore settings: the Quaternary sediments approach, Mar. Pet. Geol. 18 (2001), pp. 513-517.

International Committee of Coal Petrology, 1971 International Committee of Coal Petrology, International Handbook of Coal Petrography (2nd ed.), CNRS, Paris (1971).

Kening et al., 2004 F. Kening, J.D. Hudson, J.S. Sinninghé Damsté and B.N. Popp, Intermittent euxinia: reconciliation of Jurassic black shale with its biofacies, Geology 32 (2004), pp. 421-424.

Kolonic et al., 2002 S. Kolonic, J.S. Sinninghé Damsté, M.E. Böttcher, M.M.M. Kuypers, W. Kuhnt, B. Beckmann, G. Scheeder and T. Wagner, Geochemical characterization of Cenomano/Turonian Black shales from the Tarfaya Basin (SW Morocco). Relationships between palaeoenvironmental conditions and early sulphurization of sedimentary organic matter, J. Pet. Geol. 25 (2002), pp. 325-350.

Kuhnt and Wiedmann, 1995 W. Kuhnt and J. Wiedmann, Cenomanian-Turonian source rocks: paleobiogeographic and paleoenvironmental aspects. In: A.Y. Huc, Editor, Paleogeography, Paleoclimate, and Source Rocks, Am. Assoc. Pet. Geol. Stud. Geol. vol. 40 (1995), pp. 213-231.

Kuhnt et al., 1990 W. Kuhnt, J.P. Herbin, T. Thorow and J. Wiedmann, Distribution of Cenomanian-Turonian organic facies in the western Mediterranean and along the adjacent Atlantic margin. In: A.Y. Huc, Editor, Depositional of Organic Facies, Am. Assoc. Pet. Geol. Stud. Geol. vol. 30 (1990), pp. 133-160.

Kuhnt et al., 2001 W. Kuhnt, H. El Chellai, A. Holhoum, F. Luderer, J. Thurow, I. Wagner, A. El Albani, B. Beckmann, J.P. Herbin, H. Kawamura, S. Kolonic, S. Nederbragt, C. Street and K. Ravilious, Morocco Basin's sedimentary record may provide correlations for Cretaceous paleoceanographic events worldwide, EOS 82 (2001), pp. 361-364. 
Kuypers et al., 2002 M.M.M. Kuypers, R.D. Pancost, I.A. Nijenhuis and J.S. Sinninghe Damsté, Enhanced productivity led to increased organic carbon burial in the euxinic North Atlantic Basin during the late Cenomanian oceanic anoxic event, Paleoceanography (2002).

Lafargue et al., 1998 E. Lafargue, F. Marquis and D. Pillot, Rock-Eval 6 applications in hydrocarbon exploration, production, and soil contamination studies, Rev. Inst. Fr. Pet. 5 (1998), pp. 421-437.

Lancelot, 1980 Y. Lancelot, Birth and evolution of the "Atlantic Tethys", Mem. Bur. Rech. Géol. Min. 115 (1980), pp. 215-223.

Lancelot and Seibold, 1977 Y. Lancelot and E. Seibold, Initial reports of Deep Sea Drilling Project vol. 41, U.S. Govt. Printing Office, Washington (1977) (1259 pp.).

Largeau et al., 1986 C. Largeau, S. Derenne, E. Casadevall, A. Kadouri and N. Sellier, Pyrolysis of immature Torbanite and of the assistant biopolymer (PBR A) isolated from extant alga Botryococcus braunii. Mechanism of formation and structure of Torbanite. In: D. Leythaeuser and J. Rullköter, Editors, Advances in Organic Geochemistry 1985, Pergamon Press, Oxford (1986), pp. 1023-1032.

Larter and Horsfield, 1993 S. Larter and B. Horsfield, Determination of structural components of kerogens by the use of analytical pyrolysis methods. In: M.H. Engel and S.A. Macko, Editors, Org. Geochem. Principle and Applications, Plenum Press (1993), pp. 271-287.

Latil-Brun and Lucazeau, 1988 M.V. Latil-Brun and F. Lucazeau, Subsidence, extension and thermal history of the West African margin in Senegal, Earth Planet. Sci. Lett. 90 (1988), pp. 204-220.

Latimer and Filippelli, 2002 J.C. Latimer and G.M. Filippelli, Eocene to Miocene terrigenous inputs and export production: geochemical evidence from ODP Leg 177, Site 1090, Palaeogeogr. Palaeoclimatol. Palaeoecol. 182 (2002), pp. 151-164.

Leine, 1986 L. Leine, Geology of the Tarfaya oil shale deposit, Morocco, Geology 65 (1986), pp. 57-74.

Lewan, 1986 M.D. Lewan, Stable carbon isotopes of amorphous kerogens from Phanerozoic sedimentary rocks, Geochim. Cosmochim. Acta 50 (1986), pp. 15811591.

Lüning et al., 2003 S. Lüning, S. Kolonic, E.M. Belhadj, Z. Belhadj, L. Cota, G. Baric and $T$. Wagner, Integrated depositional model of Cenomanian-Turonian organic rich strata in North Africa, Earth, Sci. Rev. 64 (2003), pp. 51-117.

Michaud, 1984 Michaud, L., 1984. Les milieux sédimentaires crétacés du Sénégal et leur évolution diagénétique (Etude de subsurface). PhD thesis, Univ. Marseille, France. 
Morse and Berner, 1995 W.J. Morse and A.R. Berner, What determines sedimentary C/S ratio, Geochim. Cosmochim. Acta 59 (1995), pp. 1073-1077.

Müller et al., 1983 C. Müller, A. Schaaf and J. Sigal, Biochronostratigraphie des formations d'âge crétacé dans les forages du DSDP dans l'océan Atlantique Nord, Rev. Inst. Fr. Pet. 38 (1983), pp. 683-707.

Muscio et al., 1994 G.P.A. Muscio, B. Horsfield and D.H. Welte, Occurrence of thermogenic gas in the immature zone-implications from the Bakken in source reservoir system, Org. Geochem. 22 (1994), pp. 461-476.

Nzoussi-Mbassani, 2003 Nzoussi-Mbassani, P., 2003. Le Cénomano-Turoninien de l'Atlantique Nord (Bassin du Sénégal): environnement de dépôt et évolution diagénétique. Implications pétrolières. PhD thesis, Univ. Orléans, France.

Nzoussi-Mbassani et al., 2003 P. Nzoussi-Mbassani, J.-R. Disnar and F. LaggounDéfarge, Organic matter characteristics of Cenomanian-Turonian source rocks: implications for petroleum and gas exploration onshore Senegal, Mar. Pet. Geol. 20 (2003), pp. 411-427.

Oberhänsli et al., 1990 H. Oberhänsli, P. Heinze, L. Diester-Haass and G. Wefer, Upwelling of Peru during the last 430,000 yrs and its relationship to the bottom-water environments, as deduced from coarse grain-size distributions and analyses of benthic foraminifers at holes 679D, 680B, and 681B, leg 112, ODP 112 (1990), pp. 369-382.

Orgeval, 1994 J.J. Orgeval, Peridiapiric métal concentration: example of the Bougrine deposit (Tunisian Atlas). In: B. Fontbote, Editor, Sediment-hosted Zn-Pb ores, Spec. Publ.-Soc. Geol. vol. 10, Springer, Berlin (1994), pp. 354-389.

Passier et al., 1999 H.F. Passier, H.J. Bosch, I.A. Nijenhuis, L.J. Lourens, M.E. Böttcher, A. Leendres, J.S. Sinninghé Damsté, G.J. de Lange and J.W. de Leeuw, Sulphidic Mediterranean surface waters during Pliocene sapropel formation, Nature 397 (1999), pp. 146-149.

Pedersen and Calvert, 1990 T.F. Pedersen and S.E. Calvert, Anoxia vs. productivity: what controls the formation of organic-carbon-rich sediments and sedimentary rocks?, Am. Assoc. Pet. Geol. Bull. 74 (1990), pp. 454-466.

Peters and Moldowan, 1993 E.K. Peters and J.M. Moldowan, The Biomarker Guide: Interpreting Molecular Fossils in Petroleum and Ancient Sediment, Prentice Hall, Englewood Cliffs, NJ (1993).

Philip et al., 1993 J. Philip, J.F. Babinot, G. Tronchetti, E. Fourcade, L.E. Ricou, R. Guiraud, Y. Bellion, J.P. Herbin, P.J. Combes, J.J. Cornée and J. Decourt, Late Cenomanian (94 to $92 \mathrm{Ma}$ ). In: J. Dercourt, L.E. Ricou and B. Vrielynck, Editors, Atlas Tethys Palaeoenvironment Maps, Gauthier-Villars, Paris (1993), pp. 153-178. 
Philip et al., 2000 J. Philip, J.F. Babinot, G. Tronchetti, E. Fourcade, L.E. Ricou, R. Guiraud, Y. Bellion, J.P. Herbin, P.J. Combes, J.J. Cornée and J. Decourt, Late Cenomanian. In: J. Dercourt, L.E. Ricou and B. Vrielynck, Editors, Atlas Peri-Tethys, Palaeogeographical Maps. Paris, map 14 (2000).

Raiswell and Berner, 1985 R. Raiswell and R.A. Berner, Pyrite formation in euxinic and semi-euxinic sediments, Am. J. Sci. 285 (1985), pp. 710-724.

Repeta, 1993 D.J. Repeta, A high resolution historical record of Holocene anoxygenic primary production in the Black Sea, Geochim. Cosmochim. Acta 57 (1993), pp. 4337-4342.

Riboulleau et al., 2000 A. Riboulleau, S. Derenne, G. Sarret, C. Largeau, F. Baudin and J. Connan, Origin of organic sulphur compounds and sulphur-containing high molecular weight substances in sediments and immature crude oils, Org. Geochem. 13 (2000), pp. 593-606.

Romero and Hebbeln, 2003 O. Romero and D. Hebbeln, Biogenic silica and diatom thanatocoenosis in surface sediments below the Peru-Chile Current: controlling mechanisms and relationship with productivity of surface waters, Mar. Micropaleontol. 48 (2003), pp. 71-90.

Schlanger and Jenkyns, 1976 S.O. Schlanger and H.C. Jenkyns, Cretaceous oceanic anoxic events: causes and consequences, Geology 55 (1976), pp. 179-184. Abstract-Compendex

Schlanger et al., 1987 S.O. Schlanger, M.A. Arthur, H.C. Jenkyns and P.A. Scholle, The Cenomanian-Turonian oceanic anoxic event: I. Stratigraphy and distribution of organic carbon-rich beds and the marine $\partial^{13} \mathrm{C}$ excursion. In: J. Brooks and A.J. Fleet, Editors, Marine Petroleum Source Rocks, Special Publication-Geological Society of London vol. 26 (1987), pp. 371-399 (London).

Sinninghé Damsté and Köster, 1998 J.S. Sinninghé Damsté and J. Köster, A euxinic southern North Atlantic Ocean during the Cenomanian/Turonian oceanic anoxic event, Earth Planet. Sci. Lett. 158 (1998), pp. 165-173.

Sinninghé Damsté et al., 1989 J.S. Sinninghé Damsté, T.I. Englinton, J.W. de Leeuw and P.A. Schenck, Organic sulphur in macromolecular sedimentary organic matter: structure and origin of sulphur-containing moieties in kerogen, asphaltenes and coal as revealed by flash pyrolysis, Geochim. Cosmochim. Acta 53 (1989), pp. 873-889.

Sinninghé Damsté et al., 1993 J.S. Sinninghé Damsté, S.G. Wakeham, M.E.L. Kohnel, J.M. Hayes and J.W. Leeuw, A 6,000 year sedimentary molecular record of chemocline excursions in the black sea, Nature 362 (1993), pp. 827-829.

Stach et al., 1982 E. Stach, M.T. Mackowsky, M. Teichmüller, G.H. Taylor, D. Chandra and R. Teichmüller, Stach's Textbook of Coal Petrology, Gebrüder Borntraeger, Berlin (1982) (535 pp.). 
Stow et al., 2001 D.A.V. Stow, A.Y. Huc and P. Bertrand, Depositional processes of black shales in deep water, Mar. Pet. Geol. 18 (2001), pp. 491-498.

Suess, 1980 E. Suess, Particulate organic carbon flux in the ocean, Nature 288 (1980), pp. 260-263.

Teichmüller, 1982 M. Teichmüller, Origin of organic constituents of coal. In: Stach, Editor, Textbook of coal petrology, Gebrüder Borntraeger, Berlin (1982), pp. 219294.

Tissot and Welte, 1984 B.P. Tissot and D.H. Welte, Petroleum formation and occurrence, Springer-Verlag, Berlin (1984) (699 pp.).

Tyson, 1995 R.V. Tyson, Sedimentary Organic Matter. Organic Facies and Palynofaciès, Chapman and Hall, London (1995) (615 pp.).

Villeneuve and Da Rocha Araujo, 1984 M. Villeneuve and P.R. Da Rocha Araujo, La stratigraphie du bassin paléozoïque de Guinée (Afrique de l'Ouest), Bull. Soc. Géol. Fr. 32 (1984), pp. 29-40.

Waples, 1983 D.W. Waples, Reappraisal of anoxia and organic richness, with emphasis on cretaceous of North Atlantic, Am. Assoc. Pet. Geol. Bull. 67 (1983), pp. 963-978.

Wefer et al., 1990 G. Wefer, P. Heinze and E. Suess, Stratigraphy and sedimentation rates from oxygen isotope composition, organic carbon content, and grain-size distribution at the Peru upwelling region: holes 680B and 686B, ODP 112 (1990), pp. 355-362.

Wiedmann et al., 1982 J. Wiedmann, A. Butt and G. Einsele, Cretaceous stratigraphy, environment, and subsidence history at Moroccan continental margin. In: U. Von Rad, K. Hinz, M. Sarntheim and E. Seibold, Editors, Geology of the North West African Continental Margin, Springer, Berlin (1982), pp. 366-395. 